\title{
Plant-derived antimalarial agents: new leads and efficient phythomedicines. Part I. Alkaloids
}

\author{
ALAÍDE B. OLIVEIRA ${ }^{1}$, MARIA FÂNI DOLABELA ${ }^{1,2}$, FERNÃO C. BRAGA ${ }^{1}$, ROSE L.R.P. JÁCOME ${ }^{1}$, \\ FERNANDO P. VAROTTI ${ }^{1}$ and MARINETE M. PÓVOA ${ }^{3}$ \\ ${ }^{1}$ Departamento de Produtos Farmacêuticos, Faculdade de Farmácia, Universidade Federal de Minas Gerais, \\ Av. Antônio Carlos, 6.627, 31270-901 Belo Horizonte, MG, Brasil \\ ${ }^{2}$ Faculdade de Farmácia, ICS, Universidade Federal do Pará, 68075-110 Belém, PA, Brasil \\ ${ }^{3}$ Laboratório de Malária, Seção de Parasitologia, Instituto Evandro Chagas, \\ BR-316, km 7 s/n, B. Levilândia, 67030-000 Ananindeua, PA, Brasil \\ Manuscript received on January 13, 2009; accepted for publication on July 9, 2009; \\ contributed by ALAÍDE B. OLIVEIRA*
}

\begin{abstract}
Malaria remains one of the most serious world health problem and the major cause of mortality and morbidity in the endemic regions. Brazil is among the 30 high-burden countries and most of the cases occur in the Legal Amazonian Region. New chemotherapeutical agents are needed for the treatment of malaria. Many plant species are used in traditional medicines of malarious countries and a relatively few number of these have been investigated for evaluation of their antimalarial effect. Still lower is the number of those that have had the active natural compounds isolated and the toxicity determined. This area is, then, of great research interest. A discovery project of antimalarial natural products from plants traditionally used to treat malaria must include in vitro and in vivo assays as well as bioguided isolation of active compounds. The final products would be antimalarial chemical entities, potential new drugs or templates for new drugs development, and/or standardized antimalarial extracts which are required for pre-clinical and clinical studies when the aim is the development of effective and safe phythomedicines. This review discusses these two approaches, presents briefly the screening methodologies for evaluation of antimalarial activity and focuses the activity of alkaloids belonging to different structural classes as well as its importance as new antimalarial drugs or leads and chemical markers for phytomedicines.
\end{abstract}

Key words: natural products, alkaloids, antimalarial activity, medicinal plants, phytomedicines.

\section{INTRODUCTION}

Malaria remains one of the most prevalent infectious disease in the world. In 2006, there were approximately 247 million cases of malaria and 3.3 billion people that were at risk of the disease. Nearly 1 million deaths, mostly of children under the age of 5 , were caused by malaria. There are currently 109 malarious countries and territories, of which 45 are within the World Health Organization (WHO) African region (WHO 2008).

\footnotetext{
* Member Academia Brasileira de Ciências Correspondence to: Alaíde Braga de Oliveira

E-mail: alaidebraga@terra.com.br
}

Although malaria is a curable and preventable disease, its prevalence increased in the 1980s and 1990s as the parasites developed resistance to the most frequently used antimalarial drugs and the vectors became resistant to insecticides. During the 1990s, child deaths caused by malaria increased by up to two-fold in some parts of sub-Saharan Africa. The disease also re-emerged in several countries in Central Asia, Eastern Europe and South-East Asia. The majority of the cases for 2006 were estimated in Africa (86\%), followed by South-East Asia (9\%) and Eastern Mediterranean regions (3\%) (Fig. 1). 


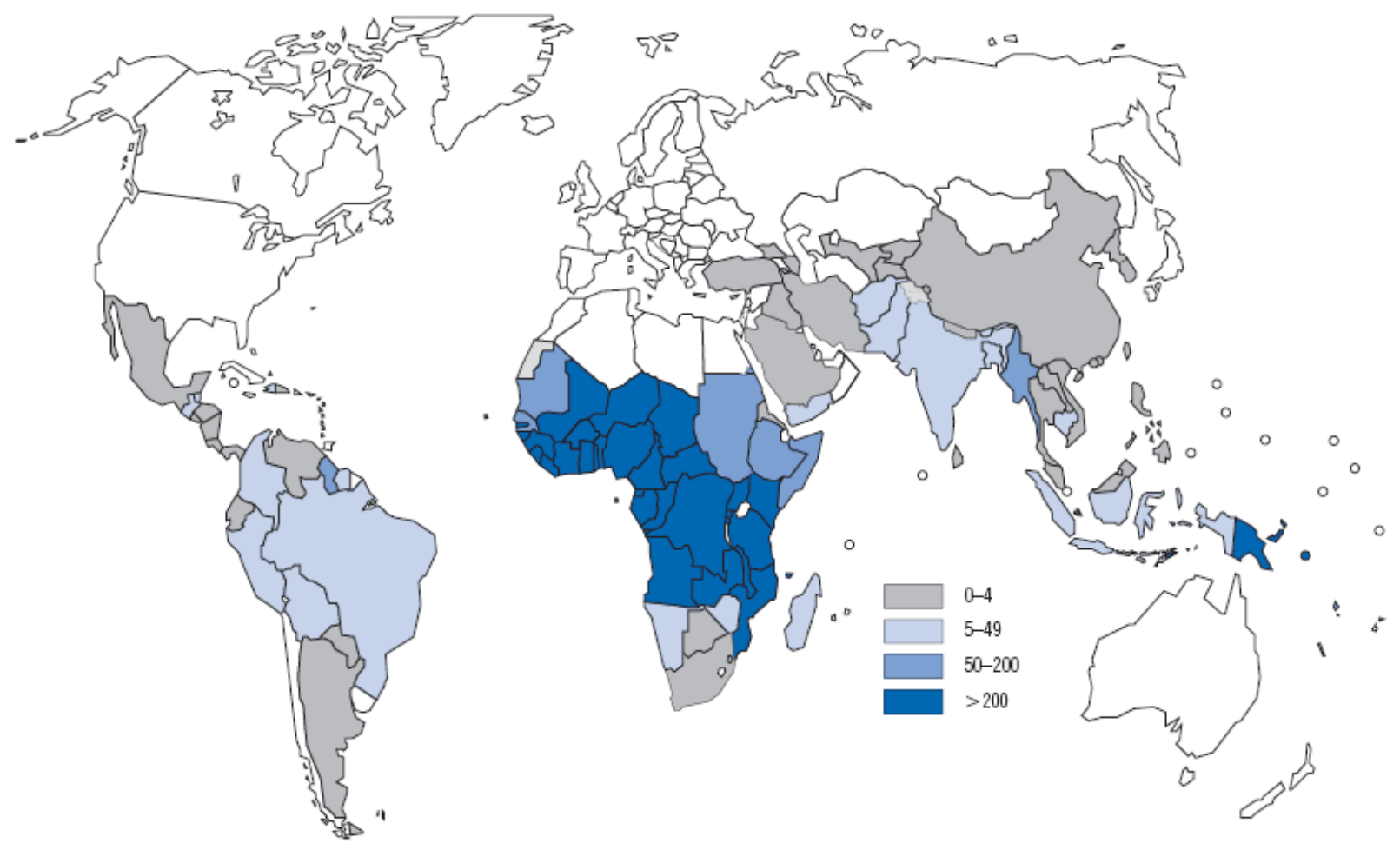

Fig. 1 - Estimated incidence of malaria per 1000 population, 2006 (WHO 2008).

In the Americas, Brazil reported the highest number of malaria cases $(549,184$ in 2007), and 1.4 million cases have been estimated. This estimate represents over half of the total number of cases for the WHO region of the Americas. More than 350,000 cases were reported annually over the period from 2001-2007, with a maximum of 603,532 cases occurring in 2005. Transmission occurred mainly in the Brazilian Legal Amazon Region, where $10-15 \%$ of the population is at risk. Almost all of the reported malaria cases in this region are confirmed. In 2007, 19\% of these were caused by $P$. falciparum. Brazil is among the thirty high-burden countries (WHO 2008). Intense migration to agricultural and mining areas in the Legal Amazon Region, in conjunction with inappropriate living conditions and inadequate health care, limits the effectiveness of interventions that are designed to control the disease. Insufficient human and other resources and technical and managerial weaknesses at the local level are also to blame (Chaves and Rodrigues 2000, Taiul 2003, WHO 2005).

To strengthen the global response to the disease, the Roll Back Malaria (RBM) Partnership was launched in 1998 by the WHO in a partnership with the United Nations Children's Fund (UNICEF), the United Nations Development Programme (UNDP) and the World Bank. The aim of this partnership was to bring together the major stakeholders in a fight against malaria. Participants included the governments of malaria-endemic countries, international organizations, private foundations, non-governmental organizations, and research and academic institutions. The principal goal was to reduce the rate of malaria-related mortality by $50 \%$ by 2010 . In 2005, the World Health Assembly resolved to "ensure a reduction in the burden of malaria of at least $50 \%$, by 2010 , and by $75 \%$, by 2015 ". This resolution has been interpreted as meaning a reduction in malaria-related morbidity as well as mortality. The reference year for measuring changes in morbidity and mortality was taken as 2000 (WHO 2008).

\section{THE DISEASE, AETIOLOGICAL AGENTS AND VECTORS}

Malaria, also known as impaludism, is an infectious disease that is caused by protozoans. Clinical manifesta- 
tions can include headache, periodically recurrent fever (every 48 to $72 \mathrm{~h}$ ), chills, myalgia, sudoresis, hepatoand splenomegalia, prostration, and the presence of high anaemia in cases of severe malaria in children and pregnant women. Severe $P$. falciparum human malaria can include neurological symptoms, such as delirium and convulsions, metabolic acidosis, multi-organ system failure and, if not properly treated, it can lead to coma and death (Fidock et al. 2004, Brasil 2006).

The aetiological agents of malaria are protozoans that belong to the genus Plasmodium, phyllum Apicomplexa, and family Plasmodidae. Four species of malaria parasites are pathogenic to humans: $P$. falciparum, $P$. vivax, $P$. ovale, and $P$. malariae. $P$. ovale seems to be limited to sub-Saharan Africa and some islands of the western Pacific, whereas $P$. falciparum and $P$. vivax are prevalent in endemic malarial countries, such as Brazil. $P$. falciparum is the agent of severe and potentially fatal human malaria (Krettli et al. 2001, Brasil 2006, 2007).

The vectors of the malarial parasites are mosquitoes of the genus Anopheles (family Culicidae). There are approximately 430 known species of Anopheles, but only 30-50 of them transmit malaria. Transmission to humans occurs via a bite of the infected female mosquito. In humans, the parasites grow and multiply, first in the liver cells, and then in red blood cells. In the liver cells, there is an initial round of replication (exo-erythrocytic schizogony), after which they undergo asexual multiplication in erythrocytes (erythrocytic schizogony). This process results in the destruction of erythrocytes and the release of daughter parasites (merozoites). The blood stage parasites are responsible for the clinical manifestations of the disease, and are the source of infection to mosquitoes (CDC 2008). Non-treated or inadequately treated individuals can be sources of infection to mosquitoes for a period of 2-3 years; the mosquitoes themselves remain infectious until death (Brasil 2006).

\section{DRUGS CURRENTLY USED FOR THE TREATMENT OF MALARIA}

The treatment of human malaria aims to interrupt the blood schizogony (intraerythrocytic asexual multiplication) that causes the pathogenesis and clinical symptoms of the infection. Prompt and effective treatment is probably the most cost-effective method of malaria control. Oral treatment prevents progression to a severe state of the disease and the resultant complications. If the drugs are administered effectively, a decrease in overall malaria-related morbidity and mortality may be achieved. However, most people living in endemic areas have little or no access to diagnosis and treatment. Furthermore, the treatment is commonly inadequate due to the lack of availability of quality-assured, effective drugs (Guérin et al. 2002, Fidock et al. 2004).

Most of the antimalarial drugs that are currently in use belong to the classes of aminoquinolines (chloroquine, amodiaquine, primaquine), quimolinomethanol derivatives (quinine, mefloquine, halofantrine), diaminopyrimidines (pyrimethamine), sulfonamides (sulfadoxine, sulfadiazine), biguanides (proguanil and derivatives), antibiotics (tetracyclines, doxycyclin, clindamycin), sesquiterpenes (artemisinin, dihydroartemisinin, arteether, artemether, artesunate) and naphtoquinones (atovaquone) (Chart 1) (Guérin et al. 2002).

The available drugs exert their effects as blood schizonticides (artemisinin and derivatives, quinolines, folate inhibitors, atovaquone). Few drugs that belong to the classes of 8-aminoquinolines and folate inhibitors are as effective as liver schizonticides (asexual liver schizogony) (Guérin et al. 2002). Primaquine, an 8aminoquinoline, is the only commercially available drug that destroys hypnozoites (a latent form of parasite that is observed in infections by $P$. vivax; it remains in the liver for variable periods of time, and causes relapses of the disease). This drug is also active against gametocytes, a human parasitic form that initiates the malarial cycle upon its ingestion by mosquitoes, (Brasil 2006).

The most widely used antimalarial drugs are chloroquine (CQ) and the combination of sulfadoxine-pyridoxamine (SP). In most regions of endemic malaria, the effectiveness of these drugs is declining at an ever accelerating rate, with consequent increases in malaria-related morbidity and mortality (Guérin et al. 2002, Fidock et al. 2004, WHO 2005).

For several decades, the gold standard for treatment of malaria was CQ; this is a 4-aminoquinoline that is characterized by its efficacy, low toxicity and low cost. Its widespread global use, which began in the 1940's, was followed a decade later by the first reports of CQ- 


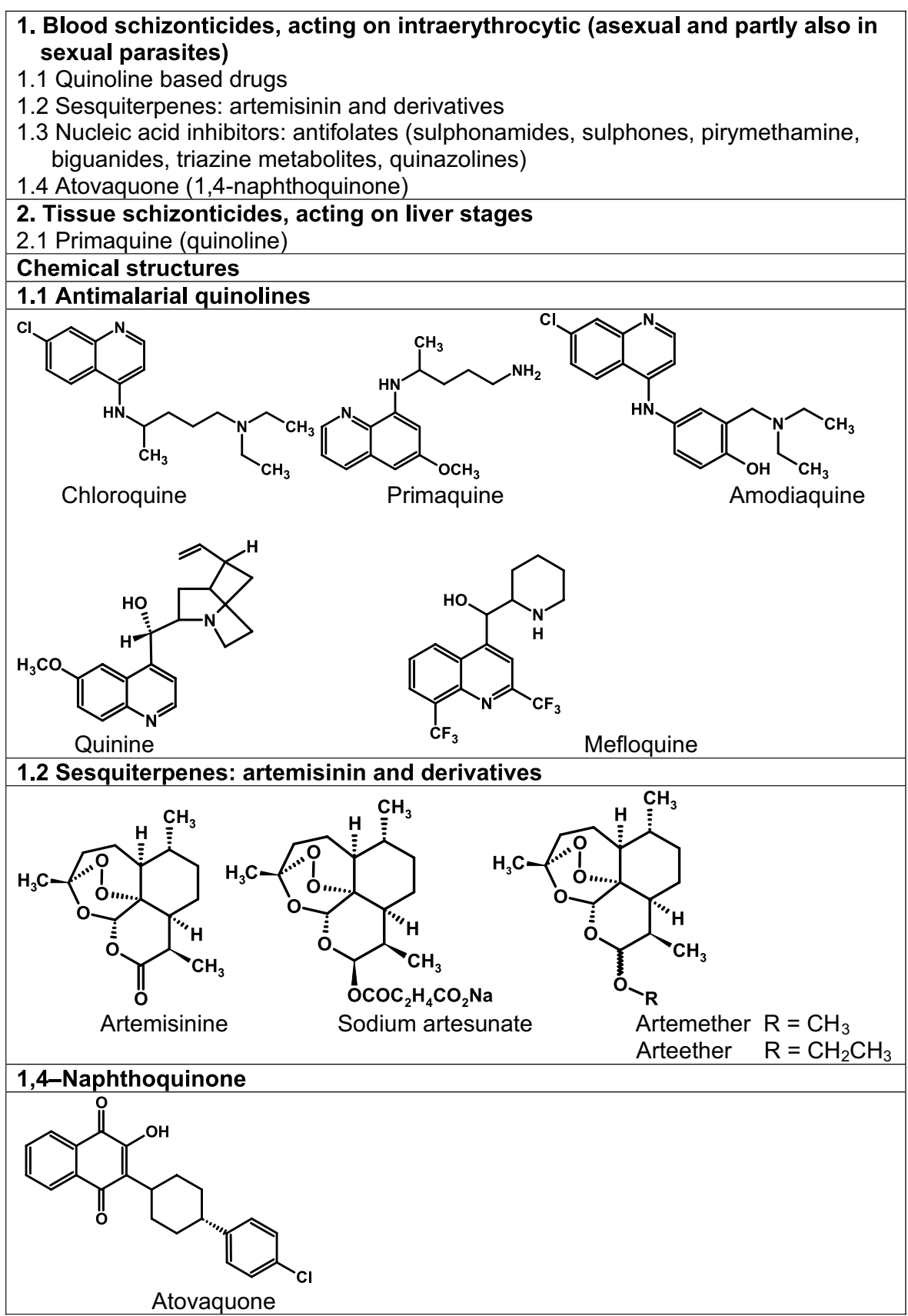

Chart 1 - Classes of antimalarial drugs in clinical use (Guérin et al. 2002).

resistant strains of $P$. falciparum. Nowadays, CQ resistance has spread to the majority of malaria endemic areas, and this drug has become increasingly ineffective (Fidock et al. 2004).

The antimalarial drug combination therapy that was proposed by the WHO in 2001 includes Artemisinin-based Combination Therapy (ACT). It combines artemisinin and its derivatives with existing antimalarial drugs. Several artemisinin-based pharmaceutical variants, including artesunate-amodiaquine, artemetherlumefantrine (Coartem $\left.{ }^{\circledR}\right)$, artesunate-mefloquine, and dihydroartemisinin-piperaquine (Artecom ${ }^{\circledR}$ ), are available. Artemether-lumefantrine $\left(\right.$ Coartem $\left.{ }^{\circledR}\right)$ is currently the most effective treatment for human falciparum 
malaria (the most lethal form of the disease). The drug has passed extensive efficacy and safety trials and is recommended as a first- or second-line treatment for uncomplicated falciparum malaria. Atovaquone-proguanil (Malarone ${ }^{\circledR}$ ) is one of the non-artemisinin combination therapies (WHO 2005, 2008).

Questions regarding the affordability and accessibility of these high cost artemisinin and atovaquone combinations for communities in poor countries (Koech 2006) are being addressed by the Roll Back Malaria (RBM) Partnership. RBM is working to make the drugs available for use in the public sector of these countries. By the end of 2006, ACT was the first-line treatment for $P$. falciparum infections in a total of 66 countries, and in almost all countries in the African, South-East Asia and Western Pacific regions. By June 2008, only four countries and territories worldwide had not yet adopted ACT as the first-line treatment for $P$. falciparum malaria. Free treatment with ACT is more widely available in the South-East Asia and Western Pacific regions than in the African Region (WHO 2008). In Brazil, the combination artemether-lumefantrine (Coartem $\left.{ }^{\circledR}\right)$ has been used for malaria falciparum since October 2006. Fortunately, the prevalent infections in Brazil are caused by $P$. vivax and $P$. malariae (Brasil 2006). The lower number of infections by $P$. falciparum is certainly an important factor that explains the affordability of this treatment in Brazil.

New antimalarial drugs are urgently needed. Not only should these drugs be efficacious against resistant $P$. falciparum strains, but, to ensure good compliance, they should provide a cure within a reasonable length of time (3 days or less), they should be safe and of low cost, and they should be available in an appropriate formulation for oral use (Wright 2005a, Fidock et al. 2004).

\section{PLANT-DERIVED ANTIMALARIAL AGENTS}

The first antimalarial drug was quinine (1). In 1820, it was isolated by the French scientists Pelletier and Caventou from the bark of the Cinchona spp. (Rubiaceae) tree that was used by Peruvian Indians. Plant materials were taken to Europe by Jesuits in the XVII century. The structure of quinine was established by Rabe in 1908, and its synthesis was accomplished in 1944 by Woodward and Doering. However, its synthetic production by industrial means is both complex and costly. Quinine is still used today, and it is currently derived by extraction from the Cinchona spp., which grow wild in South America and are cultivated in Java (Boulos et al. 1997).

Quinine was used as a template for the synthesis of CQ in 1940. Despite the prevalence of CQ-resistant $P$. falciparum strains, it was, until recently, the only drug available for malaria chemotherapy. Over the last 30 years, the situation worsened and the increasing prevalence of resistant strains of $P$. falciparum was the major factor responsible for the increase in mortality that occurred mainly in Africa (WHO 2005).

Despite intensive efforts to produce new synthetic antimalarial drugs, the most significant recent contributions came from research on medicinal plants that contained artemisinin. In 1972, this compound was isolated from Artemisia annua; this plant species has had many traditional uses in China for several millennia. Artemisinin represents a new structure of antimalarial pharmacophore that comprises an endoperoxide sesquiterpene lactone. Semi-synthetic derivatives, including arteether, artemether and sodium artesunate, are used increasingly more often (Wright 2005b). Although they are effective against CQ-resistant $P$. falciparum as single therapeutic agents, to minimize the risks of recrudescence and the development of resistance, a combination treatment with a second antimalarial drug is recommended (WHO 2005).

The newest antimalarial drug is atovaquone (Malarone $\left.{ }^{\circledR}\right)$. This synthetic 2-alkyl-3-hydroxynaphthoquinone compound is an analogue of lapachol (a prenylnaphthoquinone from the Tabebuia species (Bignoniaceae). The discovery of this drug provided a novel lead for antimalarials that resulted in the development of atovaquone. When used in combination with proguanil (Malarone ${ }^{\circledR}$ ) (Looareesuwan et al. 1999), this compound is effective for the treatment of malaria; however, the high cost of this drug precludes its wide-scale use in many malaria endemic countries (Fidock et al. 2004).

\section{APPROACHES TO ANTIMALARIAL DRUG DISCOVERY}

There are several different approaches to antimalarial drug discovery. Regardless of the approach, it is necessary to take into account specific concerns, including the need to limit the cost of drug discovery and the cost 
of the drug itself. Several important ongoing efforts include the following:

- optimization of therapy with available drugs, including the use of combined therapy;

- development of analogues of existing agents;

- discovery of natural antimalarial products;

- investigation of compounds that were originally developed to treat other diseases;

- evaluation of drug resistance reversers; and

- chemotherapeutic exploitation of novel molecular targets (Rosenthal 2001, 2003).

As the last category benefits from recent advances in both malaria research and genomics, it is most likely to result in the identification of new classes of drugs. Transgenic malaria parasites that express green fluorescent proteins have been produced. This advancement has led to the development of new high-throughput assays (HTS). As a number of new antimalarial therapies will likely be needed in the coming years, it is important to pursue multiple strategies for drug discovery (Rosenthal 2001, 2003).

Antimalarial drug development is constrained by the same factors as any drug development program; new agents must demonstrate efficacy, be safe and have additional properties that are required for the specific disease indication. In the case of malaria, the most pressing need is for a drug that can be used for widespread treatment of the disease in developing countries. Considering resource limitations in this setting, it is generally agreed that new antimalarials should be administered orally, that they should be effective with singledaily dosing, and that curative regimens should be short (ideally 1-3 days in length). Therefore, the prime consideration in antimalarial drug development is economic in nature. First, antimalarial drugs that are to be widely used in endemic areas must be very inexpensive. Indeed, considering the severe poverty that exists in most of the malarious countries and the inexpensive cost of the currently available drugs (especially chloroquine, which costs less than U\$0.1 per treatment), even U\$1 per treatment is probably restrictive. Second, since markets for malaria are primarily in poor countries, marketing opportunities are generally limited; therefore, investment in antimalarial drug discovery and development has been insubstantial and highly dependent on support from outside of the large pharmaceutical companies. Such support includes grants that are issued to academic and industry groups by research agencies and new public-private partnerships; however, this imbalance remains large (Rosenthal 2003).

\section{ANTIMALARIAL DRUG DISCOVERY: IN VITRO ASSAYS}

Most of the antimalarial drugs currently in use were not developed on the basis of rationally selected targets, but by investigation of traditional medicinal plants (quinine and artemisinin), synthesis of analogues (CQ, mefloquine, primaquine, atovaquone), chemical modification of an active natural product (arteether, artemether, artesunate), or by assaying drugs that were used against other infectious pathogens (antifolates, antibiotics) (Fidock et al. 2004).

In vitro screens for compound activity require the ability to culture P. falciparum in vitro in human erythrocytes (Trager and Jensen 1976). Typically, parasites are propagated in leukocyte-free erythrocytes with 2 $5 \%$ haematocrit at $37^{\circ} \mathrm{C}$ under a reduced oxygen atmosphere (typically $3-5 \% \mathrm{O}_{2}, 5 \% \mathrm{CO}_{2}, 90-92 \% \mathrm{~N}_{2}$ ), in tissue culture (RPMI 1640) media that contains either human serum or Albumax (a lipid-rich bovine serum albumin) (Fidock et al. 2004).

A traditional and low-cost assay for testing small numbers of samples relies on the microscopic scoring of parasitized and uninfected erythrocytes. Briefly, parasites are incubated with test samples for 48 and 72 hours, and then the parasitaemias of treated and control groups are determined by microscopically counting Giemsa-stained smears (Trager and Jensen 1976). Although this methodology is extremely labour-intensive and time consuming, it is accurate and has the advantage of permitting observation of the effect of test samples on different intraerythrocytic stages of the parasite (Fidock et al. 2004, Krettli et al. 2009).

The standardized radioisotopic protocol consists of the measurement of the uptake of $\left[{ }^{3} \mathrm{H}\right]$-hypoxanthine (which is taken up by the parasite for purine salvage and DNA synthesis) to determine the level of P. falciparum growth inhibition. In most applications, parasites 
are cultured in the presence of different concentrations of test compounds in media that contains reduced concentrations of hypoxanthine. Afterwards, $\left[{ }^{3} \mathrm{H}\right]$-hypoxanthine is added for an additional period of incubation before cell harvesting and measurement of the radioactive counts. $\mathrm{IC}_{50}$ values can be determined by linear regression analyses of the linear segments of the dose-response curves (Desjardins et al. 1979). [ $\left[{ }^{3} \mathrm{H}\right]-$ hypoxanthine incorporation is the in vitro methodology that is most commonly used to assay antimalarial activity. However, as a result of utilization of a radioactive compound, it is a somewhat costly and complex technique, which limits its utility for resource-poor institutions and high-throughput screening (Fidock et al. 2004, Krettli et al. 2009).

Recently, a protocol for chemotherapy studies was established that uses a $P$. falciparum strain transformed with the green fluorescent protein (PfGFP) that can be quickly and specifically quantified by flow cytometry. In comparison to other methodologies, the PfGFP assay showed similar results to those obtained with the standard radioisotopic method. In vivo assays that employed the rodent-parasite $P$. berghei transformed with GFP to screen for the blood schizonticidal effect have been previously reported by the same group of Brazilian researchers (Sanchez et al. 2007).

Novel DNA-based fluorimetric methods that used PicoGreen ${ }^{\circledR}$ (Invitrogen - Molecular Probes ${ }^{\mathrm{TM}}$ ) to assess the susceptibility of parasites to antiplasmodial compounds were recently reported. PicoGreen ${ }^{\circledR}$ is a fluorochrome that selectively intercalates into doublestranded DNA (dsDNA), which results in a marked increase in fluorescence emission. A positive correlation was observed between the amount of PicoGreen ${ }^{\circledR}$ fluorescence and the percentile of parasitaemia between $0.1 \%$ and $15 \%$. This method yielded $\mathrm{IC}_{50}$ values for $\mathrm{CQ}$ and pyrimethamin that were statistically similar to those obtained by use of the $\left[{ }^{3} \mathrm{H}\right]$-hypoxanthine assays of $P$. falciparum lines 3d7(CQS) and K1(CQR). Moreover, as this method is not time-consuming, it may soon replace the traditional in vitro drug sensitivity assays (Quashie et al. 2006).

Of the biochemical assays, a colorimetric method has been developed for the detection of lactate dehydrogenase (LDH); this enzyme participates in glycolysis - a cytosolic pathway used for energy production in Plasmodia. P. falciparum LDH (pLDH) has been structurally characterized and found to differ from human LDH at both the structural and immunological levels. Plasmodia species are dependent on LDH for the metabolism of carbohydrates. pLDH is used for the conversion of lactate into pyruvate, which is the last step in glycolysis; however, only pLDH can use coenzyme 3-acetylpyridine adenine dinucleotide (APAD). In the presence of APAD, the detection of LDH is specific for the parasite enzyme. Its determination is carried out in the presence of nitro blue tetrazolium (NBT) which is reduced to a formazan derivative that is detected at $650 \mathrm{~nm}$ (Wright 2005b, Fidock et al. 2004, Deharo et al. 2000).

More recently, with advances in our knowledge of the biochemistry of malarial parasites, the mechanisms of action of older drugs have been elucidated, and potential targets for new drugs have been identified (Fidock et al. 2004). Targets that are shared between the parasite and the human host offer opportunities for chemotherapy when structural differences can be exploited. About 20 potential molecular targets with known inhibitors have been identified for P. falciparum. As more parasite molecular targets are validated by genomics programmes, the use of HTS technology and other modern approaches is expected to increase (Pink et al. 2005, Itokawa et al. 2008, Queiroz et al. 2009).

For example, the antimalarial activity of the dihydrofolate inhibitors pyrimethamine and proguanil is in part due to their relative selectivity for the parasite enzyme. Other potential targets in this group are cysteine proteases and farnesyl transferases. Alternatively, targets can be selected from enzymes or biosynthetic pathways that are present in the malaria parasite, but absent in humans. Potential selective targets for antimalarial drug discovery that have recently been identified are components of type II fatty acid biosynthesis and mevalonate-independent isoprenoid synthesis pathways; this last one is now identified as the 2C-methylD-erythritol-4-phosphate (MEP) pathway. Both of these targets are present on the apicoplast - an intracellular compartment in the intra-erythrocytic P. falciparum trophozoite (Fidock et al. 2004, Rosenthal 2003).

Assays that are designed to identify compounds that bind to haem and prevent its detoxification have 
been developed (Rathore et al. 2006). Malaria parasites contain acidic food vacuoles in which erythrocyte haemoglobin is hydrolyzed. These vacuoles appear to be the site of action of a number of existing antimalarial drugs. In the oxygen-rich lysozome-like food vacuoles, several parasite proteases (for example, plamepsins, falcipain 2, metallopeptidases) participate in the hydrolysis of haemoglobin, leading to the production of $\mathrm{Fe}$ (ii) haem, which is rapidly oxidized to $\mathrm{Fe}$ (iii) haematin, before being sequestered as an inert pigment called haemozoin (also known as $\beta$-haematin or malaria pigment). Free haem is extremely toxic to the parasite as it affects cellular metabolism by inhibiting enzymes, peroxidizing membranes and producing free radicals. Therefore, detoxification of haem is absolutely necessary for uninterrupted growth and proliferation of the parasite. The detoxification of haem occurs rapidly, via polymerization into the insoluble nontoxic crystalline hemozoin that can be synthesized in the laboratory. Although haem detoxification is a unique drug target, this process is not yet fully understood (Rhatore et al. 2006, Sullivan 2002, Deharo et al. 2002).

Several antimalarials have been shown to exert their effect by interacting with haem (Rhatore et al. 2006). Among the proposed theories for the inhibition of haem detoxification, numerous studies have shown that quinolines, such as chloroquine, quinine and amodiaquine, bind noncovalently to iron protoporphyrin IX (FPIX) and prevent its conversion to non-toxic hemozoin (Rathore et al. 2006, Leed et al. 2002, Warhurst 1981).

Spectroscopic studies and conformational analyses that aimed to investigate the correlation between structural aspects of the quinolines and antimalarial activity have been described (apud Silva et al. 2005). Based on quantitative molecular modelling studies, a pharmacophore that supports binding of the quinuclidine sp3 nitrogen to the iron atom and $\pi-\pi$ interactions of the aromatic quinoline moiety with the FP IX porphyrin ring was proposed (Silva et al. 2005, 2001, 1997).

Most of these assay methodologies can be applied to pure natural or synthetic compounds, as well as to plant extracts. However, although the most extensively used techniques are the traditional microscopic and radioisotopic ( $\left[{ }^{3} \mathrm{H}\right]$-hypoxanthine) assays, the $\mathrm{LDH}$ and haem-targeted assays are being explored (Wright et al. 2001, Steele et al. 2002, Ajaiyeoba et al. 2005).

Compounds that exhibit good in vitro activity (for example, $\mathrm{IC}_{50} \leq 1 \mu \mathrm{M}$ for pure compounds) can be tested against a range of geographically distinct $P$. falciparum lines with different drug-resistance profiles. This approach will allow for determination of whether or not resistance to the existing antimalarial drugs reduces the sensitivity of the parasite to the compounds under evaluation. Crude extracts that display an $\mathrm{IC}_{50}$ $\leq 50 \mu \mathrm{g} / \mathrm{ml}$ against $P$. falciparum can be submitted to in vitro bioguided isolation-purification processes to pursue the development of pure active natural products. Promising compounds, crude extracts and semipurified extracts that display promising in vitro activity can be submitted to in vivo assays for testing of their antimalarial effects.

\section{ANTIMALARIAL DRUG DISCOVERY: IN VIVO ASSAYS}

In vivo evaluations of antimalarial activity begin with the use of the rodent malaria parasites $P$. berghei, $P$. yoelli, $P$. chabaudi and $P$. vinckei. The most widely used model for initial drug evaluation is the $P$. berghei-infected mouse model. These evaluations involve a fourday suppressive test, in which the efficacy of four daily doses is measured by comparisons of blood parasitaemia (on day four after infection) and survival times of treated and untreated mice. Test samples can be administered by intraperitoneal, intravenous, subcutaneous or oral routes. CQ is often used as a positive control. Active compounds identified in the four-day in vivo assays can subsequently be further examined through the use of several secondary tests in mice. These tests include assays that define the optimal dose, type of affected parasitic activity and potential to induce resistance (Fidock et al. 2004).

Primate models have also had an important role in preclinical development by providing a model for the final evaluation of a drug candidate prior to human studies. As primates (particularly Aotus infulatus) are susceptible to $P$. falciparum infection, they can be used as an experimental model for the pre-clinical development of antimalarial drugs (Carvalho et al. 2000, 2003). Infections caused by different strains of $P$. falciparum 
have been well characterized in both Aotus and Saimiri species, which has provided a clearer prediction of human efficacy and pharmacokinetics than rodent models. Therefore, these models present a logical transition to clinical studies (Fidock et al. 2004).

Considering the requisites for an antimalarial drug candidate (particularly with respect to low cost), a natural product can only be used if it is abundant, easily isolated and is produced in widely growing plant species or in a plant that can be cultivated. Alternatively, a less ubiquitous natural product may be produced by cultured plant tissues or may serve as a template for the synthesis of related compounds. Moreover, if an antiplasmodial natural product is derived from traditionally used plants, attention must be drawn to the rights of local peoples as set out by the Convention on Biological Diversity (CBD) that was held in Rio de Janeiro, Brazil, in 1992 and has been ratified by 170 nations.

As manufactured drugs are generally costly, exploitation of the well recognized potential of natural products is not a guarantee of low prices. This limitation is exemplified by artemisinin and its derivatives. Without the support of governmental programs, these drugs would be economically unviable and/or unaffordable to many people who live in malarious endemic areas. However, it is important to draw attention to the fact that plant-derived antimalarials have made and continue to make a great contribution to malaria chemotherapy. Not only has this approach led to the production of newer drugs, but it has also led to the discovery of new lead molecules (Kirby 1996, Wright 2005a, b).

Most of the currently used antimalarial drugs have been developed from knowledge and investigation of medicinal plants. This relationship is especially applicable to those with a reputation for use of traditional (popular, indigenous, folkloric) medicines. Extracts of a large number of plant species, including many that are used in traditional medicines, have been evaluated for in vitro antiplasmodial activity and some have been tested in vivo (usually in mice infected with $P$. berghei or P. yoelli; for reviews, see Tagboto and Townson 2001, Schwikkard and van Heerden 2002, Carvalho et al. 1991). In some cases, the active constituents have been isolated and their structures have been elucidated (for reviews, see Saxena et al. 2003, Krettli et al. 2001), but relatively few have been further studied to assess their potential as lead compounds for the development of new antimalarial drugs (Wright 2005a).

In the following section, potent, natural antiplasmodial products (with a particular emphasis on alkaloids) will be discussed. Other classes of active plant constituents will be the subject of a forthcoming publication. Finally, remarks on the use of traditional medicines and/or phytomedicines for the treatment of malaria will be made.

\section{ALKALOIDS: NEW LEADS FOR ANTIMALARIAL DRUGS?}

Alkaloids are one of the major classes of natural products that exhibit antimalarial activity. Indeed, quinine, the first antimalarial drug, belongs to this class. Over 100 alkaloids from higher plants were reported to demonstrate significant antimalarial activity in studies published from 1990 to 2000; some of these were more potent than chloroquine (Saxena et al. 2003). Herein, some of the active reported alkaloids are grouped according to their structural classes.

Bisbenzylisoquinolines are a large and diverse group of alkaloids that occur in many plant species, particularly in members of the Menispermaceae, Berberidaceae, Ranunculaceae, Annonaceae and Monimiaceae. Many of the plants that contain these compounds have reputations as medicinals in the folklore of various cultures. In an effort to discover new antimalarial agents from natural sources, Angerhofer and co-workers tested 53 bisbenzylisoquinoline alkaloids that were isolated via phytochemical studies and bioassay-directed fractionation. The cytotoxicity of the isolates was assayed against KB cells (human oral epidermoid carcinoma), and their selectivity for inhibiting the growth of intraerythrocytic malaria parasites was evaluated. The in vitro Selectivity Index (SI) for each compound has been defined as the ratio $\mathrm{ED}_{50}\left(\mathrm{~KB}\right.$ cells) $/ \mathrm{IC}_{50}$ (P. falciparum) (Angerhofer et al. 1999).

Alkaloids from Cyclea barbata, C. atjehensis, Stephania pierrei, S. erecta, Pachygone dasycarpa, Curarea candicans, Albertisia papuana (Menispermaceae), Hernandia peltata (Hernandiaceae), and Berberis valdiviana (Berberidaceae) exhibited a wide range of biological potencies in antiplasmodial assays, and the majority exhibited some degree of cytotoxicity against hu- 
man KB cells. More than half of the tested compounds showed selective antiplasmodial activity, with an SI of $>100$-fold greater toxicity towards one or both of the P. falciparum clones (D6 and W2), relative to KB cells. Three alkaloids that contained only one diaryl ether bridge were considered as promising compounds. These alkaloids combined low $\mathrm{KB}$ cell cytotoxicity with high antiplasmodial activity $\left(\mathrm{IC}_{50}<200 \mathrm{nM}\right)$ and SI $>100$ : the biscoclaurine analogues (+)-neothalibrine $\left(\mathrm{D} 6 \mathrm{IC}_{50}\right.$ $47 \mathrm{nM}$; SI 215; W2 IC $50135 \mathrm{nM}$; SI 75) and (+)-temuconine (D6 IC $213 \mathrm{nM}$, SI > 150; W2 IC IC $_{50}$ 227, SI $>140)$ and the bisreticuline derivative, $(+)$-malekulatine (D6 IC $5061 \mathrm{nM}$, SI > 490; W2 IC $_{50}$ 164, SI > 180) (Chart 2). These results show that the antiplasmodial and cytotoxic effects of bisbenzylisoquinoline alkaloids are influenced by the configuration at chiral centres and by substituents on the aromatic rings. However, it was observed that a decrease in lipophilicity, as in quaternarized or N-oxide derivatives, resulted in the loss of both toxicity and antiplasmodial activity. This loss was probably a consequence of altered membrane permeability (Angerhofer et al. 1999).

Newly identified phenolic aporphine-benzylisoquinoline alkaloids isolated from the roots of Thalictrum faberi Ulbr.(Ramunculaceae) were shown to be more active against $\mathrm{CQR}$ P. falciparum clones (W2; $\mathrm{IC}_{50}<25$ $\mathrm{ng} / \mathrm{ml}$ ) than against CQS clones (D6; $\mathrm{IC}_{50}>100 \mathrm{ng} / \mathrm{ml}$ ). Selectivity indexes ranging from 9.4 to 65.7 were observed for 3-hydroxy-6'-desmethylthalifaboramine (A), 3-hydroxythalifaboramine (B) and 6'-desmethylthalyfaboramine (C) (Chart 2), whereas these indexes were $>540$ and $>1,800$ for quinine against the P. falciparum clones W2 and D6, respectively (Lin et al. 1999).

A morphinan alkaloid, which was biogenetically derived from benzylisoquinolines via aporphines, was recently isolated from Strychnopsis thouarssi (a Menispermaceae plant species that is endemic to Madagascar) and it was named tazopsine (tazo = malaria) (Carraz et al. 2006) (Chart 2). This plant is the only ingredient in a widely used remedy that is reputed to provide specific protection against malaria. Stem bark decoction has shown weak activity against the $\mathrm{FcB} 1$ strain of P. falciparum erythrocytic stages in vitro $\left(\mathrm{IC}_{50} 34.0 \pm\right.$ $9.4 \mu \mathrm{g} / \mathrm{ml})$. The traditional use of this plant to prevent malaria led to the in vitro evaluation of its effect on liver stages of $P$. yoelli and $P$. falciparum. Bioassays of plant decoction in cultured mouse primary hepatocytes infected with $P$. yoelli sporozoites produced an $\mathrm{IC}_{50}$ of $8.5 \pm 0.7 \mu \mathrm{g} / \mathrm{ml}$ with hepatic forms that were completely eliminated at concentrations of $20 \mu \mathrm{g} / \mathrm{ml}$ or higher. Bioguided isolation of active compounds led to the identification of tazopsine, which is the major constituent of the plant material $(0.56 \% \mathrm{w} / \mathrm{w})$. However, it has been shown to be cytotoxic in mice and in cultured human cells, which has motivated the synthesis of a series of derivatives that are active against cultured P. yoelli $\left(\mathrm{IC}_{50}<50 \mu \mathrm{M}\right)$ and of which NCPtazopsine (N-cyclopentyltazopsine) (Chart 2), with the lowest $\mathrm{IC}_{50}$ value $(3.3 \pm 0.05 \mu \mathrm{M})$, is the most promising. Dose-dependent inhibition of $P$. falciparum hepatic stages was also obtained with NCP-tazopsine, whereas no detectable effect on the multiplication of in vitro cultured erythrocytic stages (3D7 and FCR3 lines) was observed. The $\mathrm{IC}_{50}$ values and the therapeutic indices for NCP-tazopsine do not differ substantially from those of licensed prImaquine. This is a novel class of antimalarial drugs with outstanding inhibitory activity against Plasmodium hepatic stages (Carraz et al. 2006).

Naphtylisoquinolines, comprising $>70$ natural alkaloids and $>150$ derivatives, are a new class of structurally unique acetate biogenetically-derived alkaloids that have been isolated from tropical lianas belonging to the families Dioncophyllaceae and Ancistrodaceae (Bringmann and Feineis 2001). Plant species of these families are widely used in the traditional medicine of West African countries, and Southern and Southeast Asia to treat malaria and other diseases, such as dysentery, leprosy, fever, and measles. Good correlations between in vitro (CQR P. falciparum NF54 strain) and in vivo (P. berghei, Anka strain) antimalarial activities were observed for representatives of this group of alkaloids. Dioncophylline C, dioncophylline B and dioncopeltine A caused complete clearance of parasites after oral administration to $P$. berghei-infected mice, without noticeable toxic effects (Bringmann et al. 2003, François et al. 1997). Korupensamine A, from Ancistrocladus korupensis, was highly active against CQR and CQS strains of $P$. falciparum with $\mathrm{IC}_{50}$ values of $24 \mathrm{ng} / \mathrm{ml}$ (NF54 strain) and $72 \mathrm{ng} / \mathrm{ml}$ (K1 strain) (Bringmann et al. 2000). Dioncophylline E, from Diconcophyllum 


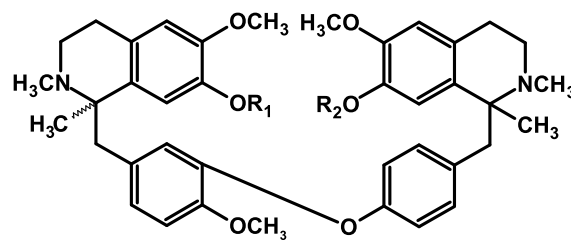

1S, $1^{\prime} \mathrm{S} ; \mathrm{R}_{1}=\mathrm{H} ; \mathrm{R}_{2}=\mathrm{CH}_{3}(+)$ - neothalibrine $1 \mathrm{R}, 1^{\prime} \mathrm{S} ; \mathrm{R}_{1}=\mathrm{CH}_{3} ; \mathrm{R}_{2}=\mathrm{H}(+)$-temuconine

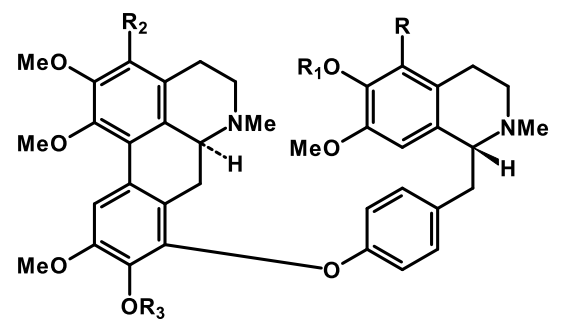

1: $\mathrm{R}=\mathrm{R}_{1}=\mathrm{H}, \mathrm{R}_{2}=\mathrm{OH}, \mathrm{R}_{3}=\mathrm{Me}$

2: $\mathrm{R}=\mathrm{R}_{3}=\mathrm{H}, \mathrm{R}_{1}=\mathrm{Me}, \mathrm{R}_{2}=\mathrm{OH}$

3: $R=R_{1}=R_{2}=R_{3}=H$

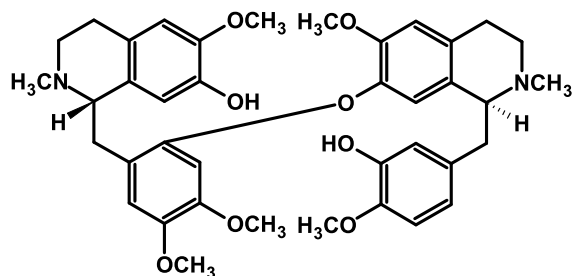

(+)-malekulatine

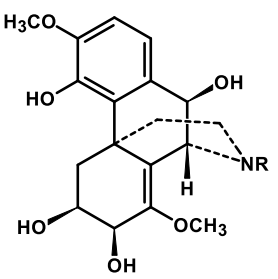

$\mathrm{R}=\mathrm{H}$, Tazopsine

$\mathrm{R}=$ cyclopentyl (semi-synthetic derivative)

Chart 2 - Structures of biogenetically derived benzylisoquinoline alkaloids with selective antiplasmodial activity (Angerhofer et al. 1999, Carraz et al. 2006).

thollonii, exists as two configurations of semi-stable atropo-diastereomers. This compound exhibited good antiplasmodial activity against both CQS (NF4 $\mathrm{IC}_{50}$ $22 \mathrm{ng} / \mathrm{ml}$ ) and CQR (K1 IC $5021 \mathrm{ng} / \mathrm{ml})$ P. falciparum strains (Chart 3). Indeed, it was only approximately 5-10 fold weaker than the standards artemisinine (2.8 and $1.1 \mathrm{ng} / \mathrm{ml}$ ) and chloroquine (4.4 and $65 \mathrm{ng} / \mathrm{ml})$ (Bringmann et al. 2002). Habropetaline A, from Tryphyophyllum peltatum (Ancistrocladaceae), displayed strong antiplasmodial activity against $P$. falciparum (K1 strain $\mathrm{IC}_{50} 1.2 \mathrm{ng} / \mathrm{ml}$; NF4 strain: $\mathrm{IC}_{50} 1.2 \mathrm{ng} / \mathrm{ml}$ ), as was expected by its close structural similarity to dioncopeltine A (Bringmann et al. 2003).

In addition to monomeric structures, the naphtylisoquinoline group of alkaloids includes a few dimeric natural derivatives. Examples of the latter include michellamines, such as michellamine B (Chart 3), which is a highly effective inhibitor of the replication of human immunodeficiency virus (HIV-1 and HIV-2). Monomeric alkaloids have been shown to be useful as building blocks or intermediates for the synthesis of novel dimeric arylisoquinoline compounds. The isolation of monomeric and dimeric arylisoquinolie alkaloids, their partial or total synthesis, the preparation of derivatives from synthetic or naturally occurring compounds, and the use of such derivatives for the prevention and treat- ment of malaria infections are the subjects of several patents (Bringmann et al. 2000).

Cryptolepine, an indoloquinoline alkaloid (Chart 4 ), is the major constituent (this alkaloid constitutes over $1 \%$ of its weight) and the most potent antiplasmodial compound derived from Cryptolepis sanguinolenta. A decoction of the roots of this climbing shrub is used in West Africa for the treatment of malaria. Furthermore, its major constituent, cryptolepine, has potent effects against both CQS (D6 $\mathrm{IC}_{50} 27.0 \pm 0.3 \mathrm{ng} / \mathrm{ml}$ ) and $\mathrm{CQR} P$. falciparum strains in vitro $\left(\mathrm{K} 1 \mathrm{IC}_{50} 33.0\right.$ $\pm 0.1 \mathrm{ng} / \mathrm{ml}$, W2 $\mathrm{IC}_{50} 41.0 \pm 0.5 \mathrm{ng} / \mathrm{ml}$; ; however, cytotoxic effects have been observed. It has been demonstrated that cryptolepine intercalates with DNA and stabilizes the topoisomerase II-DNA covalent complex; thus, the scission of DNA by topoisomerase is stimulated (Cimanga et al. 1997, Wright et al. 2001).

To assess its potential as a lead compound for antimalarial drug development, cryptolepine has been further investigated. The synthesis of cryptolepine from isatin was carried on by a three-step process. This straightforward process allowed for easy synthesis of cryptolepine analogues and supporting substituents, such as the nitro group and halogens (Chart 4). One derivative, 2,7-dibromocryptolepine, was shown to have nine-fold greater potency than cryptolepine against $\mathrm{CQR}$ 

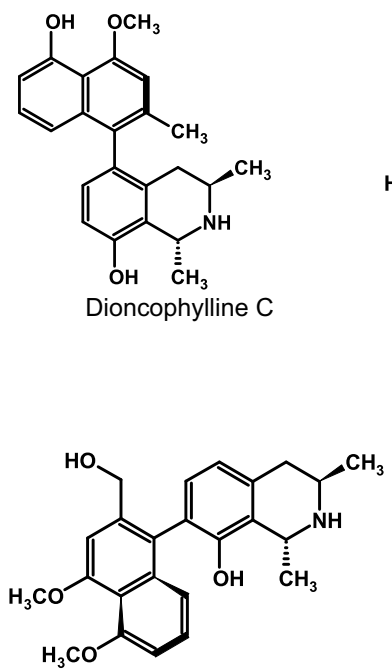

Habropetaline A

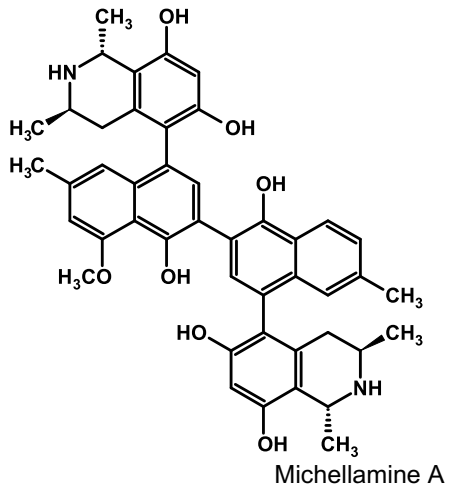

Chart 3 - Naphtyisoquinoline alkaloids: antimalarial (monomeric) and anti-HIV (dimeric) naphtylisoquinoline (François et al. 1997, Bringmann and Feineis 2001).
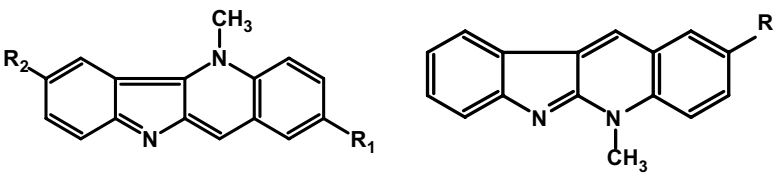

$R_{1}=R_{2}=H$, Cryptolepine

$\mathrm{R}=\mathrm{H}$, Neocryptolepine

$\mathrm{R}_{1}=\mathrm{R}_{2}=\mathrm{Br}$, 2, 7- Dibromocryptolepine $\mathrm{R}=\mathrm{Br}, 2$ - Bromoneocryptolepine

Chart 4 - Antimalarial cryptolepine, neocryptolepine and syntetic bromo derivatives (Wright 2001a, b, Jonckers et al. 2002, Wright 2005).

Plasmodium falciparum (K1). After being injected i.p. at a dose of $25 \mathrm{mg} / \mathrm{kg} /$ day into mice that were infected with Plasmodium berghei, parasitaemia was reduced by $90 \%$ and there was no apparent toxicity. Cytotoxicity was also reduced. Not only did this derivative show a lower tendency to intercalate with DNA, like cryptolepine, it also inhibited the formation of $\beta$-hematin
(Wright et al. 2001, Wright 2005a). Neocryptolepine, a minor alkaloid that is isolated together with cryptolepine from the roots of $C$. sanguinolenta, has also demonstrated antimalarial activity. It has a lower potency than cryptolepine, but it is also less cytotoxic. A series of synthetic neocryptolepine derivatives was screened and 2-bromoneocryptolepine was identified as a favourable lead compound that exhibited both good antimalarial activity ( $\mathrm{IC}_{50} 4.0 \mu \mathrm{M}, P$. falciparum $\mathrm{W} 2$ strain) and very low cytotoxicity (MRC-5 cells, $\mathrm{IC}_{50}>32 \mu \mathrm{M}$ ) (Jonckers et al. 2002).

Mono- and bis-indole alkaloids have been isolated from several plants that are traditionally used to treat malaria in different continents. The most active compounds are those that originate from plants that belong to the genera Strychnos (Loganiacae) and Alstonia (Apocynaceae). A review covering the indole alkaloids that have high antiplasmodial activities in vitro and in vivo, and favourable selectivity indices $\left(\mathrm{SI}=\mathrm{CC}_{50} / \mathrm{IC}_{50}\right)$ was published recently (Frederich et al. 2008).

The antiplasmodial activity of 69 indolomonoterpenoid alkaloids (Chart 5) from various Strychnos species (Loganiaceae) have been evaluated against CQR and CQS lines of $P$. falciparum in vitro (Frederich et al. 2002, 2003). The most active alkaloids were also tested for cytotoxicity against HCT-1116 (colon cancer cells) and their antiplasmodial SIs were calculated. Of the assayed compounds, 40 were of the mono-indole type and 24 were bis-indole alkaloids. A wide range of antiplasmodial potencies were observed $\left(\mathrm{IC}_{50}\right.$ ranged from 32 to $500 \mathrm{nM}$ ). Twelve out of the 24 bisindole alkaloids showed $\mathrm{IC}_{50}$ values $<2 \mu \mathrm{M}$ against all Plasmodium lines assayed. Most of the 12 Strychnos alkaloids tested for cytotoxicity exhibited between 5 and 400-fold higher potency against $P$. falciparum than against the evaluated cancer cell lines. This difference is indicative of the variability of antiplasmodial selectivity. The most selective compounds were isostrychnopentamine from $S$. usambarensis (with $\mathrm{IC}_{50}$ of 100 $150 \mathrm{nM}$ against all Plasmodium lines), and ochrolifuamine A from S. potatorum (with $\mathrm{IC}_{50}$ of $100-500 \mathrm{nM}$ ). The SIs for these alkaloids had ranges of 50-70 and 30140 , respectively. Dihydrousambarensine, with an $\mathrm{IC}_{50}$ of $32 \mathrm{nM}$ against CQR P. falciparum strain (W2) and SI of 375 , seemed to be the most promising of these 


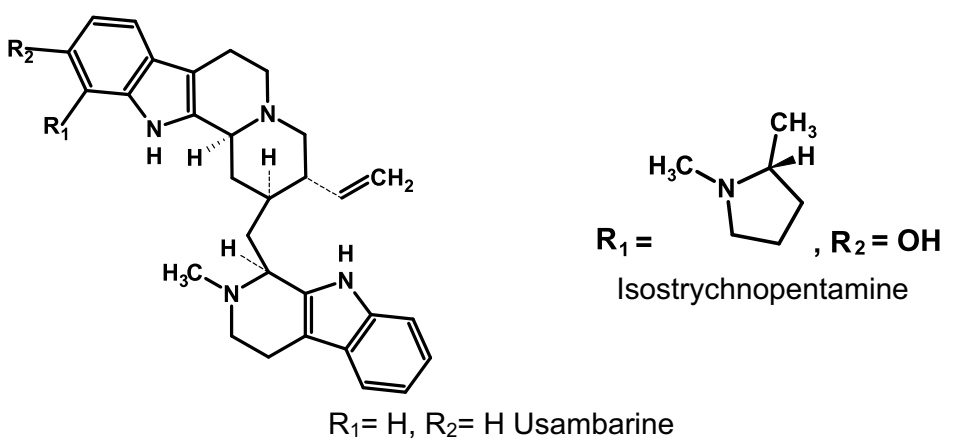

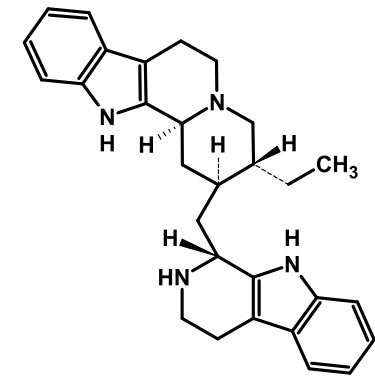

Ochrolifuanine A

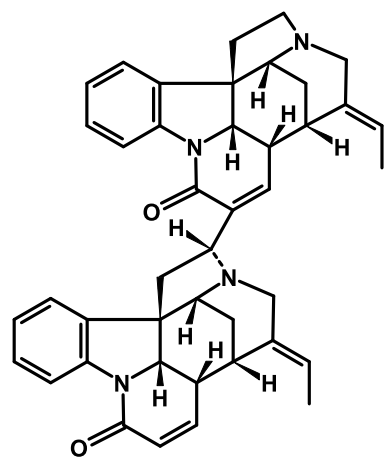

Sungucine

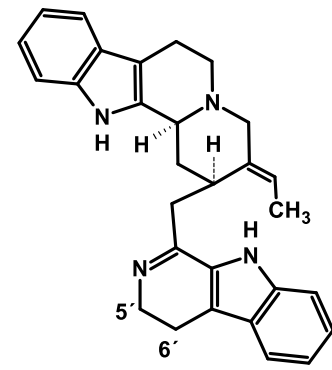

$\triangle 5^{\prime}-6^{\prime}$ Usambarensine (Dihydrousambarensine)

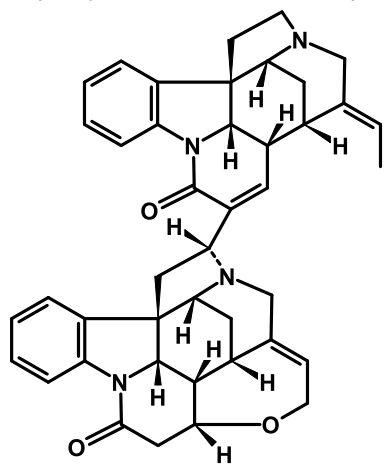

Strychnogucine B

Chart 5 - Structures of indolomonoterpenoid alkaloids from Strychnos spp. with selective antiplasmodial activity (Frederich et al. 2002, 2003).

bis-indole alkaloids (Frederich et al. 2003). However, it was inactive in $P$. berghei-infected mice at a dose of $30 \mathrm{mg} / \mathrm{kg} /$ day. Differences in the biology of CQR $P$. falciparum strains and the CQS P. berghei strain used in that study were considered to explain the negative in vivo result, since it had been shown that this alkaloid was essentially active against CQR strains of $P$. falciparum, and a CQS P. berghei strain was used in that study (Frederich et al. 1999). From S. icaja (traditionally used in Cameroon to treat malaria), several monoand bis-indole alkaloids have been isolated. The mono- indole alkaloids have not shown significant antiplasmodial activity. The most active were derivatives of the bis-indole sungucine, of which strychnogucine $\mathrm{B}$, with an $\mathrm{IC}_{50}$ of $85 \mathrm{nM}$ (W2, CQR), has shown a favourable SI (176, W2) (Philippe et al. 2007) (Chart 5).

Alstonia species (Apocynaceae) are traditionally used in Africa and South-East Asia for the treatment of malaria. The investigation of several Alstonia species, including A. angustifolia, A. scholaris, A. macrophylla, and A. glaucescens, resulted in the discovery of a series of antiplasmodial bis-indole alkaloids, of which 
villalstonine and macrocarpamine were the most active against the CQR K1 strain in vitro $\left(\mathrm{IC}_{50} 270\right.$ and $360 \mathrm{nM}$, respectively) (Wright et al. 1993, Keawpradub et al. 1999). Voacamine, isolated from Tabenamontana fuchsiaefolia A. DC. (synonym Peschiera fuchsiaefolia (DC) Miers), has been traditionally used to treat malaria in Brazil, Africa and the Dominican Republic. This compound was effective against the CQR W2 strain both in vitro and in vivo, and it had a good $\mathrm{SI}\left(\mathrm{IC}_{50}=411 \mathrm{nM}\right.$, SI = 47) (Frederici et al. 2000) (Chart 6).

Antiplasmodial indole alkaloids have recently been isolated from Geissospermum and Aspidosperma species (family Apocynaceae) that occur in tropical and sub-tropical regions of the Americas. Geisospermum is a small genus of trees (including G. laeve, G. sericeum, G. vellosii, and G. argenteum) that are found in Brazil and French Guiana, and are traditionally used for the treatment of malaria (Brandão et al. 1992, Milliken and Albert 1996, 1997, Bertani et al. 2005). These plants are traditionally consumed as bark decoctions.

The antiplasmodial activity of a hydromethanol extract of $G$. sericeum bark that was collected in the state of Roraima, in Brazil, showed an $\mathrm{IC}_{50}$ of $1.78 \mu \mathrm{g} / \mathrm{ml}$, against a CQR P. falciparum strain (K1). From alkaloidal fractions, four alkaloids were isolated: geissoschizoline and flavopereirine, which were previously isolated from $G$. vellosii and G. laeve, and geissoschizoline $\mathrm{N}^{4}$ oxide and 1,2-dehydrogeissoschizoline, which are novel natural indolomonoterpenoid derivatives (Steele et al. 2002; Chart 7). Flavopereirine, a $\beta$-carboline alkaloid, was the most active of the four compounds that were assayed against K1 (CQR) and T9-96 (CQS) strains of $P$. falciparum $\left(\mathrm{IC}_{50}=11.53\right.$ and $1.83 \mu \mathrm{M}$, respectively), but it also showed moderate cytotoxicity against KB cells $\left(\mathrm{IC}_{50}=10.7 \mu \mathrm{M}\right)$, with essentially no selectivity against the $\mathrm{K} 1$ strain. Geissoschizoline and its $\mathrm{N}^{4}$-oxide lacked both cytotoxicity and antiplasmodial activity at $40 \mu \mathrm{M}$. The 1,2-dehydro derivative showed moderate antiplasmodial activity against both $\mathrm{K} 1$ and T9-96 strains ( $\mathrm{IC}_{50}$ of 27.26 and $35.37 \mu \mathrm{M}$, respectively) and some selectivity was indicated by the finding that less than $50 \%$ inhibition of $\mathrm{KB}$ cells was observed at $40 \mu \mathrm{M}$, using the MTT method. It should be emphasized that the crude $\mathrm{MeOH}-\mathrm{H}_{2} \mathrm{O}(9: 1)$ extract was shown to have greater antiplasmodial activity than the isolated alka- loids. In addition, even the alkaloidal fractions obtained by sequential extractions with $\mathrm{Et}_{2} \mathrm{O}, \mathrm{CHCl}_{3}$ and $\mathrm{EtOAc}$ were less active (with $\mathrm{IC}_{50}$ values of $10.15,2.21$ and $2.47 \mu \mathrm{g} / \mathrm{ml}$, respectively). This result suggests that compounds other than alkaloids might be responsible for the antiplasmodial activity of $G$. sericeum (Steele et al. 2002). The antiplasmodial activity displayed in vitro by the crude extract of $G$. sericeum and some of its alkaloidal constituents seem to confirm earlier reports describing the traditional use of this plant for the treatment of malaria by populations from the Amazonia region (Milliken and Albert 1997, Brandão et al. 1992).

Up to 1983, 46 species of Aspidosperma had been chemically investigated (Bolzani et al. 1987). This number increased to 55 by 1996 (Pereira et al. 2007). Hundreds of indolomonoterpenoid alkaloids have been isolated and their structures have been determined mainly by spectrometric methods. These compounds represent a valuable library of rich structural diversity and great interest for bioprospection. In fact, an antineoplasic drug, Elliptinium (Celiptium ${ }^{\circledR}$ ) (9-hydroxy-2-methylellipticinium acetate) is a semi-synthetic derivative of the cytotoxic alkaloid ellipticine (Chart 8); it was initially isolated from the Ochrosia species (Apocynaceae) but it also occurs in the Aspidosperma species (Pereira et al. 2007). Elliptinium is marketed in France for the treatment of breast cancer (Cragg and Newman 2005).

Aspidosperma spp., which is found from Mexico to Argentina (Marcondes-Ferreira Neto 1988), is another genus of the Apocynaceae family that includes some species that have been traditionally used for the treatment of malaria. These species include $A$. nitidum (Brandão et al. 1992), A. desmanthum (Milliken and Albert 1997), A. auriculatum (Barbosa et al. 2003), and A. megalocarpon (Weniger et al. 2001). Further investigation of the Aspidosperma species, as part of the quest for bioactive alkaloids, has been a task of phytochemists for the last few years (Weniger et al. 2001, Mitaine-Offer et al. 2002, Jácome et al. 2004, AndradeNeto et al. 2007).

Eleven known aspidospermane alkaloids have been isolated from $A$. pyrifolium and $A$. megalocarpon (both of which originated from Bolivia), and one semi-synthetic alkaloid derivative was assayed for the first time for its in vitro antiplasmodial activity and cytotoxicity 

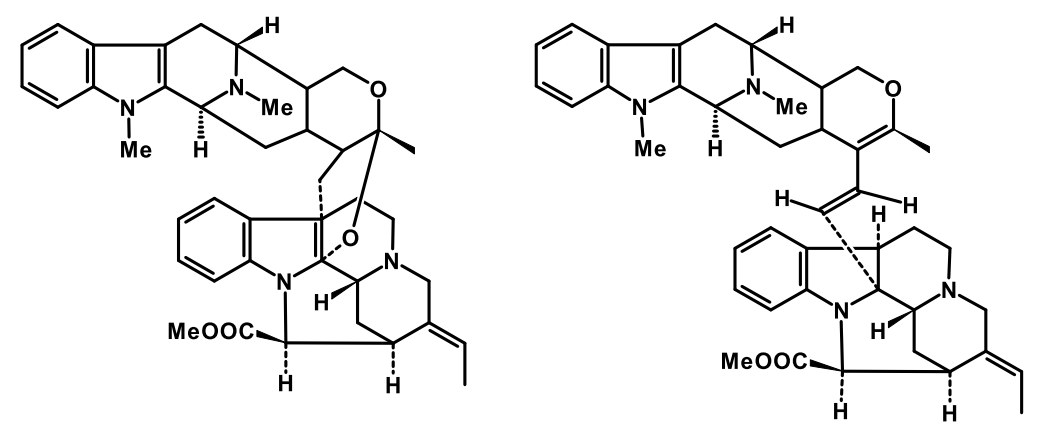

Villalstonine

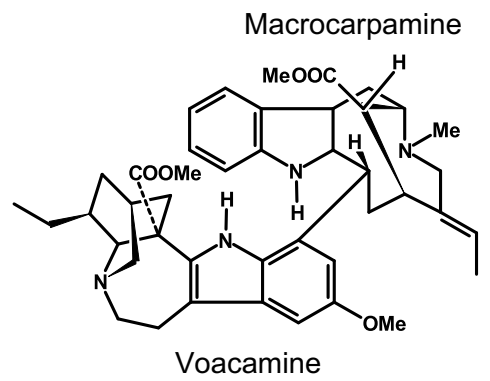

Chart 6 - Structures of indolomonoterpenoid alkaloids from Alstonia spp. with selective antiplasmodial activity (Frederici et al. 2000).

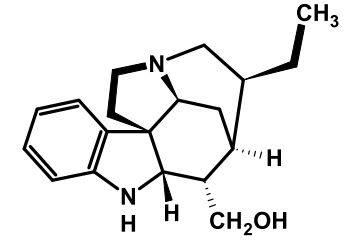

Geissoschizoline

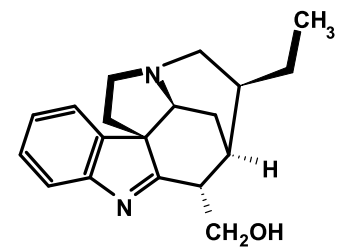

1,2-Dehydrogeissoschizoline

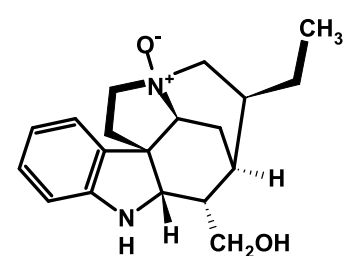

Geissoschizoline $\mathrm{N}^{4}$ - oxide

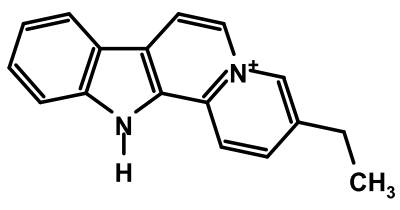

Flavopereirine

Chart 7 - Structures of indole and $\beta$-carboline alkaloids from Geissospermum sericeum (Steele et al. 2002).<smiles>Cc1c2ccncc2c(C)c2c1[nH]c1ccccc12</smiles>

Ellipticine<smiles></smiles>

Ellipticinium<smiles>CCC12CCCN3CCC4(c5ccc(O[N+](=O)[O-])c(O)c5N(C(C)=O)[C@H]4CC1)C32</smiles>

Aspidocarpine

Chart 8 - Structures of ellipticine, an antitumoral natural alkaloid, aspidocarpine, an antiplasmodial alkaloid, and ellipticinium, a syntetic anticancer drug. 

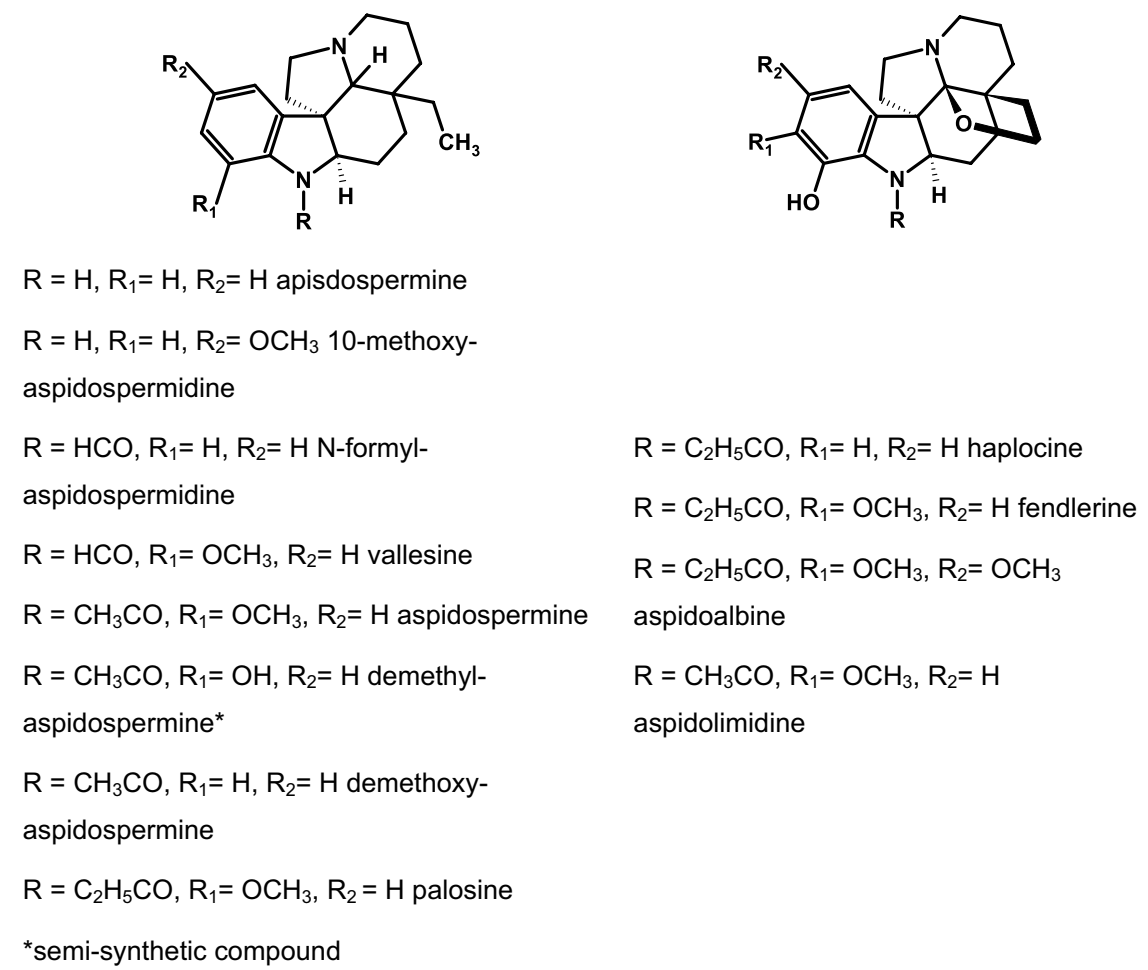

Chart 9 - Antiplasmodial aspidospermane alkaloids from Aspidosperma pyrifolium and A. megalocarpon (Mitaine-Offer et al. 2002).

(Mitaine-Offer et al. 2002; Chart 9). CQR (FcM29 Cameroon) and CQS (Nigeria) isolates of P. falciparum were used for evaluation after $24 \mathrm{~h}$ and $72 \mathrm{~h}$. Cytotoxicity against the human fibroblast cell line (NIH 3T3) was determined after $24 \mathrm{~h}$ and $72 \mathrm{~h}$, which allowed for estimation of the SIs for antiplasmodial activity. Most of the alkaloids that have been assayed have demonstrated better antiplasmodial activity after incubation for $72 \mathrm{~h}$. According to the $\mathrm{IC}_{50}$ values, the compounds were ranked into one of two groups: the most active (eight alkaloids), with $\mathrm{IC}_{50}$ values between 3.2 and $15.4 \mu \mathrm{M}$, and the less active ones (four alkaloids), with $\mathrm{IC}_{50}$ values between 22.6 and $52.6 \mu \mathrm{M}$. The first group of compounds is structurally characterized by the presence of a free ethyl group, whereas the corresponding carbons are involved in a tetrahydrofuran ring in the less active alkaloids. The three most active antiplasmodial compounds, 10methoxy-aspidospermidine, N-formyl-aspidospermine, and aspidospermine (Chart 9), were shown to be less cytotoxic. The SIs for these alkaloids, after $72 \mathrm{~h}$, were 22.7, 15.6 and 8.3, respectively (Mitaine-Offer et al. 2002).
Once again, the antiplasmodial activity of constituents from plants that have been traditionally used to treat malaria was experimentally confirmed. Indeed, the antiplasmodial activity of a crude extract of A. megalocarpon that was collected in Bolivia and assayed against F32 and D2 strains of P. falciparum ( $\mathrm{IC}_{50}$ of 25 and $8 \mu \mathrm{g} / \mathrm{ml}$, respectively) has been previously reported (Deharo et al. 2001).

Recently, ellipticine and aspidocarpine (Chart 8) were isolated from the trunk bark of Aspidosperma vargasii and $A$. desmanthum, respectively. Both of these were collected from the Ducke Reserve, in Manaus, state of Amazonas, Brazil, and have shown a remarkable in vitro activity against the multi-drug resistant $\mathrm{K} 1$ strain of $P$. falciparum (with $\mathrm{IC}_{50}$ values of 73 and $19 \mathrm{nM}$, respectively) (Andrade-Neto et al. 2007). Ellipticine is highly cytotoxic and was used as a template for the development of Elliptinium (Celliptium ${ }^{\circledR}$ ), an antitumoural drug that is in clinical use (Cragg and Newman 2005). The production of a semi-synthetic derivative or synthetic analogue of ellipticine displaying lower cyto- 
toxicity and, thus, a favourable antimalarial selectivity is expected (Andrade-Neto et al. 2007).

Plants belonging to the Rutaceae family are a source of different classes of alkaloids, such as benzophenantridines, quinolines, furoquinolines, 2-alkylquinolines and acridines (Michael 2003, Waterman 1999). Representatives of these classes have been found in species that have folkloric antimalarial reputations and their antiplasmodial activities have been evaluated (summarized in the following section).

Benzofenantridine alkaloids (Chart 10) were isolated by bioassay-guided fractionation of the trunk bark of Zanthoxylum rhoifolium; this species was traditionally used in French Guiana to treat and prevent malaria. The antiplasmodial activity was concentrated in the alkaloid fraction, which comprised seven benzophenantridine alkaloids, of which nitidine was the most potent against $P$. falciparum $\left(\mathrm{IC}_{50}<0.27 \mu \mathrm{M}\right)$. The investigation of a trunk bark decoction that was employed as a traditional remedy revealed the presence of alkaloids, including nitidine; therefore the traditional use of $Z$. rhoifolium for the treatment of malaria was justified (Julian et al. 2006). Zanthoxylum species are frequently used to treat malaria in Madagascar. Z. tsihamimposa is used either alone or in combination with other plants to relieve malarial symptoms, such as tiredness and muscular aches. Five alkaloids that were isolated from the stem bark were assayed in vitro for antiplasmodial activity against $P$. falciparum (FCM 29); $\mathrm{IC}_{50}$ values in the range of 459.1 to $87.7 \mu \mathrm{M}$ were obtained. The most potent alkaloid was the quinolone $\gamma$ fagarine, which had an $\mathrm{IC}_{50}$ of $98.4 \mu \mathrm{M}$ (Randrianarivelojosia et al. 2003; Chart 10). Nitidine was also isolated by biossay-guided fractionation of extracts from Toddalia asiatica, a Rutaceae used by the Pokot tribe of Kenya as the major antimalarial component. Fractions containing nitidine showed $\mathrm{IC}_{50}$ values against $P$. falciparum in the range of 9 to $108 \mu \mathrm{g} / \mathrm{ml}$. Moreover, no cross-resistance was observed between chloroquine and nitidine (Gakunju et al. 1995).

From Esenbeckia febrifuga, a Rutaceae plant species popularly used in Brazil to treat malaria, $\gamma$-fagarine and skimmiamine were shown to be the most active of the five alkaloids that were isolated (Chart 10). Skimmiamine was more potent against the $\mathrm{W} 2 \operatorname{strain}\left(\mathrm{IC}_{50}=\right.$
$75.3 \pm 2.7 \mu \mathrm{M} ; 19.5 \pm 0.7 \mu \mathrm{g} / \mathrm{ml})$, whereas $\gamma$-fagarine was more active against the $3 \mathrm{~d} 7 \mathrm{strain}\left(\mathrm{IC}_{50}=109.8 \pm\right.$ $18.3 \mu \mathrm{M} ; 25.0 \pm 4.2 \mu \mathrm{g} / \mathrm{ml})$. However, an ethanol extract from the stems was more active $\left(\mathrm{IC}_{50}=15.5 \pm\right.$ $0.7 \mu \mathrm{g} / \mathrm{ml}$ ) than either of these alkaloids, which indicates the existence of more active, non-isolated compounds or synergy between the various constituents (Dolabela et al. 2008).

Seven alkaloids were isolated from Teclea trichocarpa (synon. Toddalia trichocarpa) from Kenya. Of these alkaloids, two (normelicopicine and arborinine) displayed limited in vitro activity against $P$. falciparum strains (HB3 and K1). Normelicopicine was also shown to be active against $P$. berghei-infected mice (32\% suppression of parasitaemia at a dose of $25 \mathrm{mg} / \mathrm{kg} /$ day) in addition to having low in vitro $\mathrm{KB}$ cell cytotoxicity $\left(\mathrm{IC}_{50}>328 \mu \mathrm{M}\right)$ (Mauriithi et al. 2002; Chart 10).

Acridone alkaloids derived from species that belong to the genera Citrus (Glycosmis and Severimia) and are members of the family Rutaceae were tested for antimalarial activity in vitro against $P$. yoelli and in vivo against $P$. berghei- and $P$. vinckei-infected mice. At a concentration of $10 \mu \mathrm{g} / \mathrm{ml}$ in vitro, seven out of the 30 tested alkaloids inhibited $90 \%$ or more of the parasite growth. Against P. yoelli, they were shown to be either equally or more effective than chloroquine in vitro $(94 \%$ \pm 4 growth inhibition). Of the seven or more active alkaloids, atalaphillinine was the only one to be tested for in vivo activity. A daily dose of $50 \mathrm{mg} / \mathrm{kg}$ of this alkaloid was injected i.p. into mice for a period of three days. Marked prophylactic activity against $P$. berghei- and $P$. vinckei-infected mice was observed by days 4 and 5 after infection. Very few intraerythrocytic parasite forms were seen in blood smears and they had completely disappeared by day 9 or 10 . No sign of recrudescence was observed on day 30. Moreover, no obvious acute toxicity was observed in mice for 30 days after administration, whereas all control mice died between days 6 and 8 . No acute toxic effect was observed after injection (i.p.) of a single dose of $150 \mathrm{mg} / \mathrm{kg}$ into mice (Fujioka et al. 1989; Chart 10).

Furoquinoline and acridine alkaloids have been isolated from plants that belong to the Rutaceae family. The in vitro and in vivo activities of acridones against rodent malaria (Fujioka et al. 1989) and the in vitro ef- 
<smiles>COc1cc2c[n+](C)c3c4cc5c(cc4ccc3c2cc1OC)OCO5</smiles><smiles>COc1ccc2c(OC)c3ccoc3nc2c1OC</smiles>

Skimmiamine<smiles>COc1cc2c(c(O)c1OC)c(=O)c1ccccc1n2C</smiles>

Aorborinine<smiles>COc1cc2c(c3c(=O)c4ccccc4n(C)c13)C=C(O)C(C)(C)O2</smiles>

Acronycine<smiles>COc1c2ccoc2nc2c(OC)cccc12</smiles>

$\gamma$-Fagarine<smiles>COc1c(OC)c(O)c2c(c1O)c(=O)c1ccccc1n2C</smiles>

Normelicopicine<smiles>CC1(C)C=Cc2c(ccc3c(=O)c4ccccc4[nH]c23)O1</smiles>
Atallaphillinine

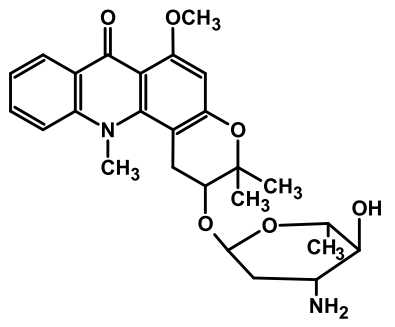

Dihydroacronycine glycoside

Chart 10 - Antiplasmodial alkaloids from Rutaceous plant species.

fect of 23 furoquinoline and acridone alkaloids against CQR (W2) and CQS (HB3) clones of P. falciparum have been reported (Basco et al. 1994). The assayed alkaloids included isolates from three New Caledonian plants (Geijera balansae, Sarcomelicope glauca and Sarcomelicope dogniensis) and derivatives that were obtained by chemical modifications and the dimerization of acronycine. Fourteen alkaloids had $\mathrm{IC}_{50}<$ $10 \mu \mathrm{g} / \mathrm{ml}$ against the $\mathrm{W} 2$ strain. Most of the active alkaloids were more than twice as active against the resistant clone than they were against the susceptible one. The most active alkaloid was an O-pyranoglycoside derivative of acronycine (Chart 10), which had an $\mathrm{IC}_{50}$ of $0.60 \mu \mathrm{g} / \mathrm{ml}$ (Basco et al. 1994).

Acronycine (Chart 10) also exhibits antitumor activity. Its toxicity was investigated in mice and its clin- ical efficacy and tolerance were evaluated in a phase II study. However, acronycine was only moderately active against $P$. falciparum $\left(\mathrm{IC}_{50}\right.$ of 7.03 and $1.44 \mu \mathrm{g} / \mathrm{ml}$ in HB3 and W2 strains, respectively) (Basco et al. 1994).

Natural and synthetic acridones are of great biomedical interest for their potential as anticancer, antimicrobial, antiviral and antiparasitic agents (Winter et al. 2006). However, only moderate antimalarial activity has been reported for acridones (Basco et al. 1994, Fujioka et al. 1989), which has motivated a recent re-investigation of commercially available compounds by Winter and collaborators (2006). The surprisingly high activity of 2-methoxy-6-chloroacridone (which displayed an $\mathrm{IC}_{50}$ of $45 \mathrm{nM}$ against the D6 strain of P. falciparum (CQR)) has stimulated the synthesis of haloalkoxyacridones, a new class of chemical entities with an extraor- 
<smiles>[R]Oc1ccc2[nH]c3cc(Cl)ccc3c(=O)c2c1</smiles>

$\mathrm{R}=\mathrm{CH}_{3}, 2$-methoxy-6-choroacridone $\mathrm{R}=\mathrm{H}$, 2-hydroxy-6-chloroacridone<smiles>O=c1c2ccc(Cl)cc2[nH]c2cc(OCCCCC(F)(F)F)ccc12</smiles>

3-(6, 6, 6)-Trifluorohexyloxy-6-chloroacridone

Chart 11 - Antimalarial synthetic haloalkoxy-acridones (Winter et al. 2006).<smiles>CCCCC1CCc2ccccc2N1C</smiles>

Angustureine<smiles>COc1ccc(CCCC2CCc3ccccc3N2C)cc1OC</smiles><smiles>COc1cc(CCCC2CCc3ccccc3N2C)ccc1O</smiles>

Galipeine

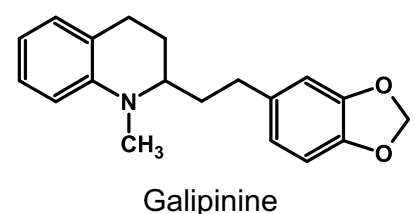

Chart 12 - Antiplasmodial tetrahydroquinoline alkaloids from Galipea officinalis (Jacquemond-Collet et al. 2002).

dinary potential for development as therapeutic agents to treat or prevent malaria in humans. The influence of substituents at positions 2, 3 and 6 of the tricyclic acridone skeleton was investigated, and led to the development of over 30 synthetic derivatives. The in vitro activities of these derivatives were evaluated against D6 (CQR) and Dd2 (multidrug-resistant) strains of $P$. falciparum. The results clearly point to the influence of an ether group at position 2, with the corresponding phenolic derivatives displaying significantly decreased antimalarial activity. This effect is exemplified by 2hydroxy-6-chloroacridone, which showed $\mathrm{IC}_{50}$ values of 190 and $260 \mathrm{nM}$ on D6 and Dd2 strains, respectively. A similar profile was observed for substitutions at position 3. The most potent synthetic acridones supported O-alkyl chains that terminated in trifluoromethyl groups at positions 2 or 3 of the tricyclic system. These compounds exhibited in vitro antimalarial $\mathrm{IC}_{50}$ values in the nanomolar and picomolar ranges, and were not cytotoxic to cultured murine splenic lymphocytes at concentrations that were up to 100,000-fold higher. The most potent antimalarial compound ever synthesized or tested in a laboratory (as asserted by Winter and col- laborators) had an $\mathrm{IC}_{50}$ value of approximately $1 \mathrm{pM}$. It was proposed that the haloalkoxyacridones exert their effects through inhibition of a $P$. falciparum mitochondrial component - the cytochrome bc 1 complex (Winter et al. 2006; Chart 11).

The genus Galipea (family Rutaceae) contains approximately 14 species, which occur across Central America (Costa Rica, Panama, Guatemala, Nicaragua), in Southern Brazil and Bolivia, and in other parts of South America (Pirani 2004).

Tetrahydroquinoline alkaloids were isolated from the trunk bark of G. officinalis (Chart 12). This traditional medicinal plant from Venezuela, commonly named angostura bark, is reputed to be the source of a tonic and stimulant that is used against fever (Jacquemond-Collet et al. 1999). Hexane, chloroform extracts and pure alkaloids were tested for their in vitro activity against $P$. falciparum strains. The $\mathrm{IC}_{50}$ values ranged from 1.8 to $40.0 \mu \mathrm{g} / \mathrm{ml}$ against a CQS strain (Nigerian) and 0.09 to $38.0 \mu \mathrm{g} / \mathrm{ml}$ against CQR strains (FcB1 and FcM29). With an $\mathrm{IC}_{50}$ of 0.09 to $0.9 \mu \mathrm{g} / \mathrm{ml}$, against CQR strains, galipinine was the most active alkaloid. The cytotoxicity of the extracts and of the pure alkaloids was 
assessed on a HeLa cell line. $\mathrm{IC}_{50}$ values ranged from 5.8 to $>50 \mu \mathrm{g} / \mathrm{ml}$, and the SI for galipinine varied from 10 (Nigerian strain) to $>100$ (FcM29 strain, $24 \mathrm{~h}=$ $91.5 ; 72 \mathrm{~h}>5000$ ) (Jacquemond-Collet et al. 2002).

\section{TRADITIONAL ANTIMALARIAL PLANTS}

The traditional use of plants for the treatment of human malaria and fevers all over the world has been widely documented. The number of investigations into their effects in vitro and in vivo is increasing; however, little is known about their efficacy and safety. The validation of plants that are traditional treatments for malaria is currently stimulating the interest of researchers across the world. A significant development in this area was the founding of RITAM (Research Initiative on Traditional Antimalarial Methods). The aim of this global network, which was initiated by Dr. G. Bodeker, Oxford, UK, is to further research on the traditional medicines for malaria and to make a significant contribution to global malaria control through the use of plantbased antimalarials, insect repellents and vector control. RITAM has established international partnerships with over 30 countries, including African countries (Willcox and Bodeker 2004).

A review by Willcox and Bodeker (2004) on traditional herbal medicines for malaria in three continents revealed that 1277 plant species from 160 families have been classified according to their importance for the treatment of malaria. However, only eight clinicallycontrolled trials have thus far been reported; these have involved falciparum and vivax malaria. It would be worth mentioning the results that have been obtained with Cryptolepis sanguinolenta, Artemisia annua and Dichroa febrifuga. C. sanguinolenta (aqueous extract) has been revealed to be a promising treatment for malaria falciparum; not only was the time taken for parasite clearance (3.3 days) only one day longer than that observed with CQ (2.2 days), but the clearance of the fever was achieved in a shorter time than with CQ (36 and 48 hours, respectively). A trial that compared quinine with infusions of $A$. аппиа for the treatment of malaria falciparum also demonstrated good parasite clearance with the plant infusions (at day 7, 77\% for A. апnиа infusion and $91 \%$ for quinine); however, recrudescence was experienced by a high proportion of patients. Earlier studies (in 1947 in China) had reported good results, but undesirable side effects with Dichroa febrifuga (apud Willcox and Bodeker 2004).

In South America, the RAVREDA (Rede Amazônica de Vigilância da Resistência a Drogas Antimaláricas - Amazonian Network for Vigilance of Antimalarial Drug Resistance), which was created in 2001, is a project whose goal is to furnish technical support to governmental actions that are aimed at controlling malaria in the Legal Amazon region (PAHO 2007). This project is supported by USAID (United States Agency for International Development), and the regional South American net is under the coordination of the Pan American Health Organization - PAHO (Organização Pan-Americana da Saúde - OPAS). The participating countries are Brazil, Bolivia, Equator, Guiana, Peru, Suriname and Venezuela (Brasil 2007). However, unlike RITAM, the RAVREDA project does not include research on antimalarial plants.

\section{CONCLUDING REMARKS}

The alkaloid quinine, which is derived from the South American Cinchona species, was traditionally used as an antimalarial remedy by the Incas in Peru. It was the first drug to be introduced for malaria chemotherapy and served as a template for the synthesis of chloroquine (a quinoline that has been used since the 1940's). The potential of alkaloids as antimalarials has been widely documented and concisely presented in this paper. As some of the active plants that produce alkaloids carry a reputation for traditional usage, further investigations that include both pre-clinical and clinical assays are encouraged. Moreover, the pharmacokinetic properties of crude and semi-purified plant extracts can be improved by appropriate formulation using pharmaceutical technology.

In this regard, current research on new antimalarial agents faces two distinct avenues: the search for new chemical entities (NCE) of natural or synthetic origin, and the development of phytomedicines.

The naturally-occurring, antiplasmodial/antimalarial alkaloids that have been described in this short review can be divided into two groups: the first group contains highly-active compounds that have complex structures, and for which no possibility of practical synthesis can be foreseen, and the second group comprises com- 
pounds with moderate to low activity that possess relatively simple structures. The synthesis of compounds and/or their analogues from the latter group could be undertaken. Plant species that produce alkaloids of the first group are potential candidates for the development of phytomedicines, whereas alkaloids from the second group could represent templates for the production of synthetic drugs.

Will the research on traditional plants contribute to the discovery of new antimalarial drugs? Of this, there is no doubt. Atovaquone, artemisinin and its semisynthetic derivatives are remarkable examples of the diverse contribution of natural products to the development of effective antimalarial drugs. These drugs are particularly valuable for the treatment of chloroquineresistant parasites.

Although several potent antiplasmodial alkaloids have been described in this review, most of them have only been evaluated using in vitro assays. Few of them have been evaluated for cytotoxicity, and even smaller is the number of those that have been assayed in vivo. As many of these compounds are found in low concentrations in various plant species and usually as part of complex mixtures, their isolation and purification are highly expensive. In these situations, the benefits to be obtained from the development of phytomedicines (with the known active compounds being useful as chemical or biological markers to guarantee product quality) are evident.

The validation of traditional plant remedies has limitations, such as the prioritization of plant species for research, a lack of information on the ethnobotany of these plants (location and abundance, parts used, form of use, duration of treatment), and the definition of dosages due to variations in the concentrations of active ingredients in a plant species (Willcox and Bodeker 2004, Bourdy et al. 2007). For each of these questions, there are scientific and technical solutions. At the present time, the more serious questions concern biodiversity, property rights, equitable distribution of benefits from the use of traditional medicines, and their sustainable use and conservation.

It should be stressed that a basic requirement for the validation of a medicinal plant is the standardization of the extracts that are to be evaluated. Standardiza- tion includes identification and quantification of chemical and/or biological markers to ensure the development of efficient and safe phytomedicines in a short period of time and at a low cost. It is well known that both the qualitative and quantitative contents of secondary metabolites in a plant are susceptible to marked variations; these contents are influenced by intrinsic factors (ontogeny and phenology), abiotic factors (light, moisture, nutrient availability), and biotic factors (different physiological and growth stages; Harborne 2001). As a result, standardization is obligatory.

Finally, we present a streamlined process adapted from Fidock and collaborators (2004) emphasizing the role of traditional medicinal plants in the research and development of antimalarial phytopharmaceuticals (new drugs and/or phytomedicines) (Fig. 2).

\section{ACKNOWLEDGMENTS}

To Conselho Nacional de Desenvolvimento Científico e Tecnológico ( $\mathrm{CNPq}$ ) and Fundação de Amparo à Pesquisa do Estado de Minas Gerais (FAPEMIG) for financial support and fellowships (CNPq IA/ABO, II/ FCB; FAPEMIG PDJ/FPV). To Dr. Luzia H. Carvalho (CPRR/FIOCRUZ, Belo Horizonte, MG) for valuable suggestions.

\section{RESUMO}

A malária ainda é um dos mais sérios problemas de saúde pública e a principal causa de mortalidade e morbidade nas regiões endêmicas. O Brasil está entre os 30 países com maior incidência de malária e a maior parte dos casos ocorre na Amazônia Legal. Novos agentes terapêuticos são necessários para o tratamento da malária. Muitas espécies vegetais são utilizadas na medicina tradicional de vários países endêmicos mas é relativamente reduzido o número daquelas que já foram investigadas quanto à sua atividade antimalárica. Menor ainda é o número de espécies das quais foram isoladas substâncias ativas e tiveram sua toxidade determinada. Esta área de pesquisa é, portanto, de alta relevância. Um projeto de descoberta de produtos naturais antimaláricos a partir de plantas de uso tradicional deve incluir ensaios in vitro e in vivo bem como o isolamento biomonitorado de substâncias ativas. Os produtos finais serão substâncias naturais antimaláricas, potenciais fármacos ou protótipos para o desenvolvimento de 


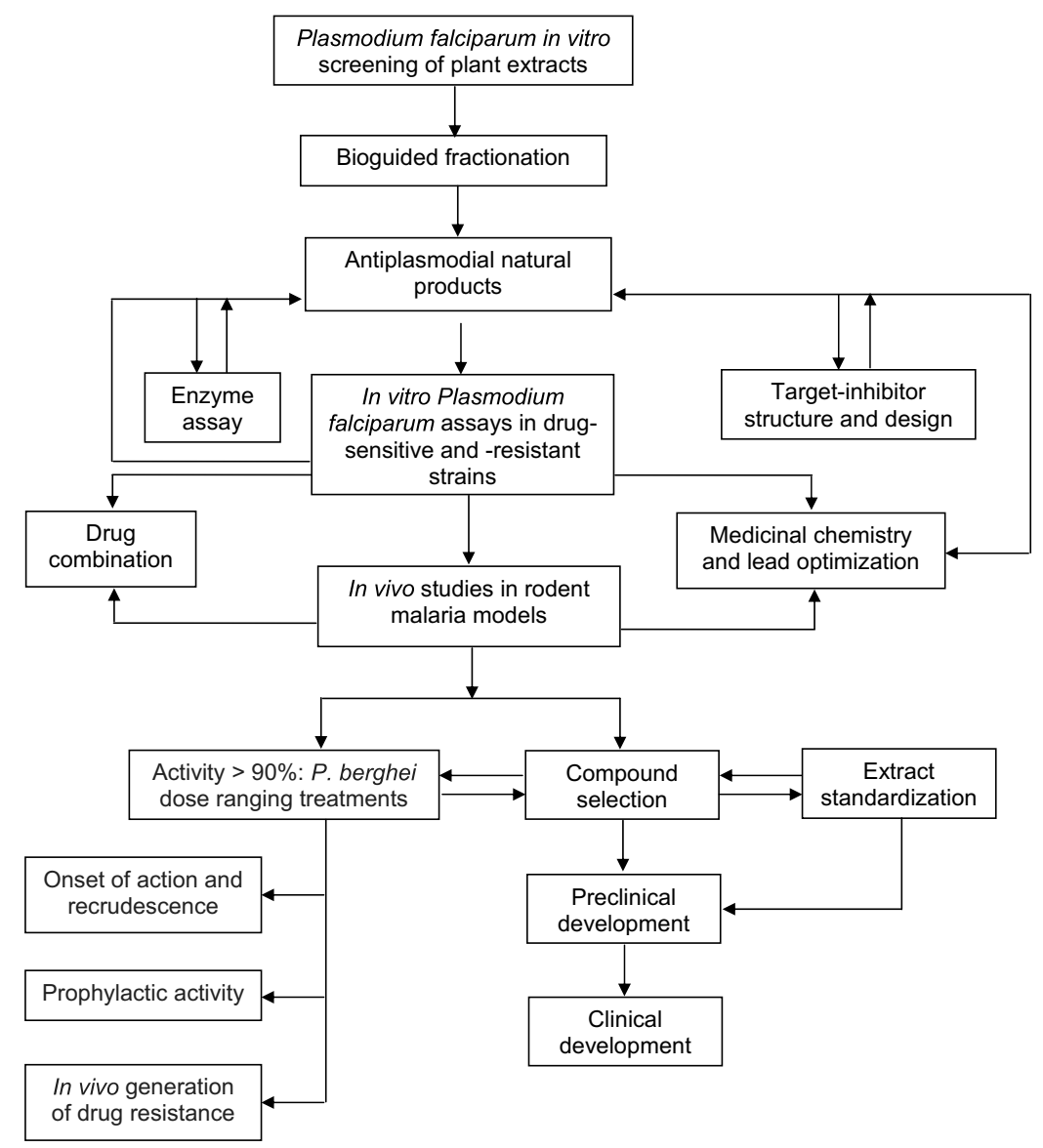

Fig. 2 - General approach for antimalarial drug discovery and phytomedicines development (adapted from Fidock et al. 2004). Discovery starts with Plasmodium falciparum in vitro screening of plant extracts, followed by bioguided fractionation of active extracts, resulting in the isolation of antiplasmodial compounds. At this stage, active target enzymes can be employed in biochemical screens, which may well support molecular modeling and design of potential active compounds, based on target-inhibitor interactions. In vitro assays comprise determination of $\mathrm{IC}_{50}$ against sensitive and resistant strains of Plasmodium falciparum and such results may allow selecting templates for chemical optimization. In vivo assays include tests for suppression of parasitaemia in rodents. In combination, in vitro and in vivo studies are directed towards template selection. Compounds showing activity above $90 \%$ are subjected to further studies aiming at evaluating recrudescence, prophylactic efficacy and resistance development. Alternatively, standardized extracts (phytomedicines) could be developed in a shorter and less expensive pipeline.

novos fármacos, e/ou extratos padronizados, com atividade antimalárica, os quais são necessários para estudos pré-clínicos e clínicos quando o objetivo é o desenvolvimento de fitoterápicos (fitomedicamentos) eficazes e seguros. A presente revisão discute estas duas abordagens, apresenta resumidamente as metodologias de bioensaios para avaliação de atividade antimalárica e focaliza a atividade de alcalóides pertencentes a diferentes classes estruturais bem como sua importância como fármacos ou protótipos e como marcadores químicos de fitoterápicos.

Palavras-chave: produtos naturais, alcalóides, atividade antimalárica, plantas medicinais, fitoterápicos.

\section{REFERENCES}

Ajaiyeoba E et AL. 2005. Antimalarial ethnobotany: in vitro antiplasmodial activity of seven plants identified in the Nigerian middle belt. Pharm Biol 42: 588-591.

ANDRADE-NETO VF ET AL. 2007. In vitro inhibition of Plasmodium falciparum by substances isolated from Amazonian antimalarial plants. Mem Inst Oswaldo Cruz 102: 359-365.

Angerhofer CK, Guinaudeau H, Wongpanich V, Pezzuto JM ANd Cordell GA. 1999. Antiplasmodial and cytotoxic activity of natural bisbenzylisoquinoline alkaloids. J Nat Prod 62: 59-66. 
Barbosa WLR, Tavares ICC And SoAres DC. 2003. Alcalóides de Aspidosperma auriculatum Standl. Rev Bras Farmacognosia 13: 06-08.

Basco LK, Mitaku S, Skaçtsounis AL, RavelomaNAntsoa N, Tillequin F, Koch M And Bras JL. 1994. In vitro activities of furoquinoline and acridone alkaloids against Plasmodium falciparum. Antimicrob Agents Chemother 38: 1169-1171.

Bertani S, Bourdy G, Landau I, Robinson JC, EsTERRE P AND DEHARO E. 2005. Evaluation of French Guiana traditional antimalarial remedies. J Ethnopharmacol 98: 45-54.

Bolzani VS, Serur LM, Matos FJA amd Gottlieb OR. 1987. Indole alkaloids evolution in Aspidosperma. Biochem Syst Ecol 15: 187-200.

Boulos M, Dutra AP, Disanti SM, Shiroma M And Amato Neto V. 1997. Avaliação clínica do quinino para o tratamento da malária por Plasmodium falciparum. Rev Soc Bras Med Trop 30: 211-213.

Bourdy G, Willcox ML, Ginsburg H, Rasoanaivo Ph, Graz B ANd Deharo E. 2007. Ethnopharmacology and malaria: New hypothetical leads or old efficient antimalarials? Intern J Parasitol 38: 33-41.

BRANDÃo MGL, GRANDI TSM, ROCHA EMM, SAWYER DR AND KRETtli AU. 1992. Survey of medicinal plants used as antimalarials in the Amazon. J Ethnopharmacol 36: 175-182.

BRASIL. 2006. Ministério da Saúde. Secretaria de Vigilância em Saúde. Departamento de Vigilância Epidemiológica. Ações de controle da malária: manual para profissionais de saúde básica. Brasília, Editora Ministério da Saúde, $52 \mathrm{p}$.

BRASIL. 2007. Ministério da Saúde Secretaria de Vigilância em Saúde. Situação epidemiológica da malária no Brasil, $12 \mathrm{p}$.

BRINGMANN G AND FEINEIS D. 2001. Stress-related polyketide metabolism of Diocophyllaceae and Ancistrocladaceae. J Exp Bot 52: 2015-2022.

BRINGMANN G, Boyd MR AND Wenzel M. 2000. Monomeric and dimeric arylisoquinoline alkaloids and derivatives thereof. US Patent 6,140,339. Issue date: 31 Oct 2000.

Bringmann G, Messer K, Wolf K, MÜhlbacher J, GRÜNE M AND LouIS AM. 2002. Dioncophylline E from Dioncophyllum thollonii, the first 7,3'-coupled dioncophyllaceous naphthylisoquinoline alkaloid. Phytochem 60: 389-397.
Bringmann G, Messer K, Schwöbel B, Brun R AND ASSI LA. 2003. Habropetaline A, an antimalarial naphthylisoquinoline alkalaoid from Triphyophyllum peltatum. Phytochem 62: 345-349.

CDC - Center for Disease Control. 2008. Malaria. Biology. Accessed on 08/12/2008: http://www.cdc.gov/ malaria/biology /index.htm.

CARraz M ET AL. 2006. A plant-derived morphinan as a novel lead compound active against malaria liver stages. PLoS Medicine 3: 2392-2402.

Carvalho LH, Brandẽo MGL, Santos-Filho D, Lopes JLC AND KRetTli AU. 1991. Antimalarial activity of crude extracts from brazilian plants studied in vivo in Plasmodium berghei-infected mice and in vitro against Plasmodium falciparum in culture. Brazilian $\mathrm{J}$ Med Biol Res 24: 1113-1123.

Carvalho LJM, Oliveira SG, Alves FA, Brigido MC, Muniz JÁ And DANiel-Ribeiro CT. 2000. Aotus infulatus is susceptible to P. falciparum infection and may constitute an alternative experimental model for malaria. Mem Inst Oswaldo Cruz 95: 363-365.

Carvalho LJM, Alves FA, Oliveira SG, VAlle RDR, FERnANDES AAM, Muniz JÁ AND DANIEl-Ribeiro CT. 2003. Severe anemia affects both splenectomized and non-splenectomized P. falciparum infected Aotus infulatus monkeys. Mem Inst Oswaldo Cruz 98: 679-686.

Chaves SS And Rodrigues LC. 2000. An initial examination of the epidemiology of malaria in the state of Roraima, in the Brazilian Amazon basin. Rev Inst Med Trop São Paulo 42: 269-275.

Cimanga K, Bruyne TD, Pieters L and Vlietinck AJ. 1997. In vitro and in vivo antiplasmodial activity of cryptolepine and related alkaloids from Cryptolepis sanguinolenta. J Nat Prod 60: 688-691.

Cragg GM AND Newman DJ. 2005. Plants as source of anticancer agents. J Ethnopharm 100: 72-79.

Deharo E, Gautret, Muñoz V and Sauvain M. 2000. Técnicas de laboratório para la selección de substancias antimaláricas. Imprensa Perez. La Paz: CYTED, $187 \mathrm{p}$.

Deharo E, Bourdy G, Quenevo C, Muñoz V, Ruiz G AND SAUVAIN M. 2001. A search for natural bioactive compounds in Bolivia through a multidisciplinary approach. Part V. Evaluation of the antimalarial activity of plants used by the Tacan Inidians. J Ethnopharmacol 77: 91-98.

Deharo E, Garcia RN, Oprto P, Gimenez A, SAuvin M, Julitan V AND Ginsburg H. 2002. A nonradio- 
abelled ferriprotoporphyrin IX biomineralization inhibition test for the high throughput screening of antimalarial compounds. Exp Parasitol 100: 252-256.

DesJardins RE, CANFIELd CJ, HAYNEs JD AND CHUlay JD. 1979. Quantitative assessment of antimalarial activity in vitro by a semiautomated microdilution technique. Antimicrob Agents Chemother 16: 710-718.

Dolabela MF, Oliveira SG, Nascimento JM, Peres JM, Wagner H, Póvoa MM and Oliveira AB. 2008. In vitro aniplasmodial activity of extract and constituents from Esenbeckia febrifuga, a plant traditionally used to treat malaria in the Brazilian Amazon. Phytomedicine 15: 367-372.

Fidock DA, Rosenthal PJ, Croft SL, BRUn R AND NWAKA S. 2004. Antimalarial drug discovery: efficacy models for compound screening. Nature Rev Drug Discovery 3: 509-520.

François G, Timperman G, Eling W, Ake Assi L AND BRINGMANN G. 1997. Naphtylisoquinoline alkaloids against malaria: Evaluation of the curative potential of dioncophylline $\mathrm{C}$ and Dioncopeltine A against Plasmodium berghei in vivo. Antimicrob Agents Chemother 41: 2533-2539.

Frederich M, HayrtTe MP, Tits M, De Mol P Amd ANGENOT L. 1999. In vitro activities of Strychnos alkaloids and and extracts against Plasmodium falciparum. Antimicrob Agents Chemother 43: 2328-2331.

FREDERICH M, JACQUIER MJ, THÉPENIER P, MOL PD, Tits M, Philippe G, Delaude C, Angenot L and Ż̀ches-HAnRot M. 2002. Antiplasmodial activity of alkaloids from various Strychnos species. J Nat Prod 65: 1381-1386.

Frederich M, Tits M AND Angenot L. 2003. Indole alkaloids from Strychnos species and their antiplasmodial and cytotoxic activities. Chem Nat Comp 39: 513519.

Frederich M, Tits M And Angenot L. 2008. Potential antimalarial activity of indole alkaloids. Trans Royal Soc Trop Med Hyg 102: 11-19.

Frederici E, Palazzino G, Nicoletti M and GaçefFI C. 2000. Antiplasmodial activity of the alkaloids of Peschiera fuchsiaefolia. Planta Med 66: 93-95.

FUJIOKA H, NishiYAma Y, FURUKAWA H AND KUMADA N. 1989. In vitro and in vivo activities of atalaphilline and related acridone alkaloids against rodent malaria. Antimicrob Agents Chemother 33: 6-9.

Gakunju DM, Mberu EK, Dossaji SF, Gray Al, WAigh RD, WATERMAN PG AND WATKINS WM.
1995. Potent antimalarial activity of the alkaloid nitidine, isolated from a Kenyan herbal remedy. Antimicrob Agents Chemother 39: 2606-2609.

Guérin PJ, Olliaro P, Nosten F, Druilhe P, LAXMINARAYAN R, BINKA F, KILAMA W, FORD N AND White NJ. 2002. Malaria: current status of control, diagnosis, treatment, and a proposed agenda for research and development. Lancet Infect Dis 2: 564-573.

HARborne JB. 2001. Twenty-five years of chemical ecology. Nat Prod Rep 18: 361-379.

ITOKAWA H, MORRIS-NATSCHKE SL, AKIYAMA T AND LEE KH. 2008. Plant-derived natural product research aimed at new drug discovery. Nat Med (Tokio) 62(3): 263-280.

JÁCOME RLP, OliVEIRA AB, RASLAN DS AND WAGNER H. 2004. Estudo químico e perfil cromatográfico das cascas de Aspidosperma parvifolium A. DC. ("Pau-Pereira"). Química Nova 27: 897-900.

Jacquemond-Collet I, Hannedouche S, Fabre N, Fourasté I AND Moulis C. 1999. Two tetrahydroquinoline alkaloids from Galipea officinalis. Phytochem 51: $1167-1169$.

JACQUEMOND-COLLET I, BEnOIT-Vical F, VALEnTin A, Stanislas E, Mallie M and Fouraste I. 2002. Antiplasmodial and cytotoxic activity of galipinine and other tetrahydroquinolines from Galipea officinalis. Planta Med 68: 68-69.

JONCKERS THM ET AL. 2002. Synthesis, cytotixicity, antiplasmodial and anti-trypanosomal activity of new neocryptolepine derivatives. J Med Chem 45: 3497-3508.

Julian V, Bourdy G, Georges S, Maurel S and SAUVAIN M. 2006. Validation of use a traditional antimalarial remedy from French Guiana, Zanthoxylum rhoifolium Lam. J Ethnopharmacol 106: 348-352.

Keawpradub N, Kirby GC, Steele JCP and HoughTON PJ. 1999. Antiplasmodial activity of extracts of three Alstonia species from Thailand. Planta Med 65: 690-694.

KIRBY GC. 1996. Medicinal plants and the control of parasites. Medicinal plants and the control of protozoal disease, with particular reference to malaria. Trans Roy Soc Trop Med Hyg 90: 605-609.

KOECH DK. 2006. Acessibility and affordability of malaria intervention, treatment and prevention in Africa. African J Health Sci 13: 1-2.

Krettli AU, Andrade-Neto VF, Brandẽo MGL And FERRARI WMS. 2001. The search for new antimalarial 
drugs from plants ramdomly selected: a review. Mem Inst Oswaldo Cruz 96: 1033-1042.

Krettli AU, Adebayo JO And Krettli LG. 2009. Testing of natural products and synthetic molecules aiming at new antimalarials. Curr Drug Targets 10(3): 261-270.

Leed A, Dubay K, Ursos LM, Sears D, De Dios AC AND ROEPE PD. 2002. Solution structures of antimalarial drug-heme complexes. Biochemistry 41: 1024510255 .

Lin lZ, Hu SF, Chu M, Chan TM, Chai H, ANgerhofer CK, Pezzuto JM ANd Cordell GA. 1999. Phenolic aporphine-benzylisoquinoline alkaloids from Thalictrum faberi. Phytochem 50: 829-834.

LooAREesuwan S, ChUlay JD, CANFIELD CJ AND HUTCHINSON DD. 1999. Malarone (atovaquone and proguanyl hydrochloride): a review of its clinical development for treatment of malaria. Malarone Clinical Trials Study Group. Am J Trop Med Hyg 60: 533-541.

Marcondes-Ferreira Neto WM. 1988. Aspidosperma Mart. nom. cons. Apocynaceae: estudos taxonômicos. Tese de Doutorado. Universidade de Campinas. Campinas, SP, Brasil.

Mauritthi MW, Abraham WR, Addae-Kyereme J, SCOWEN I, CROF SL, GITU PM, KENDRICK HENM AND WRIGHT CW. 2002. Isolation and in vitro antiplasmodial activities of alkaloids from Teclea trichocarpa: in vivo antimalarial activity and X-ray crystal structure of normelicopicine J Nat Prod 65: 956-959.

MiChAEL JP. 2003. Quinoline, quinazoline and acridone alkaloids. Nat Prod Rep 20: 476-493.

Milliken W. 1997. Traditional antimalarial medicine in Roraima, Brazil. Econ Bot 51: 212-237.

Milliken W And Albert B. 1996. The use of medicinal plants by the Yanomami Indians of Brazil. Econ Bot 50: $10-25$.

Milliken W And Albert B. 1997. The use of medicinal plants by the Yanomami Indians of Brazil, Part II. Econ Bot 51: 264-278.

Mitaine-Offer AC, Sauvain M, Valentin A, CalLAPA J, Mallié M And Zèches-Hanrot M. 2002. Antiplasmodial activity of Aspidosperma indole alkaloids. Phytomedicine 9: 142-145.

PAHO - THE PAN AMERiCAN HeAlth ORganization. 2007. RAVREDA-AMI: Amazon Network for the Surveillance of Antimalarial Drug Resistance (RAVREDA)/ Amazon Malaria Initiative (AMI). www.paho.org/ (English/AD/DPC/CD/ravreda-ami.htm, August 30.
Pereira MM, JÁcome RlRP, Alcantara AFC, Alves RB AND RASLAN DS. 2007. Alcalóides indólicos de espécies do gênero Aspidosperma (Apocynaceae). Química Nova 30: 970-983.

Philippe G, De Mol P, Angenot L, Tits M And FreDERICH M. 2007. In vivo antimalarial activity of isosungucine, an indolomonoterpenic alkaloid from Strychnos icaja. Planta Med 73: 478-479.

Pink R, Hudson A, Mouriés MA ANd Bendig M. 2005. Opportunities and challenges in parasitic drug discovery. Nature Rev Drug Discov 4: 727-740.

PIRANI JR. 2004. Three new species of Galipea (Rutaceae, Galipeinae) from Brazil. Bot J Linnean Soc 144: 365373.

QUASHIE NB, KONING HP AND RANFORD-CARTWRIGH LC. 2006. An improved and highly sensitive microfluorimetric method for assessing suceptibility of Plasmodium falciparum to antimalarial drugs in vitro. Malaria J 5: 95101.

Queiroz EF, Wolfender JL and Hostettmann K. 2009. Modern approaches in the search for new lead antiparasitic compounds from higher plants. Curr Drugs Targets 10: 202-211.

RANDRIANARIVELOJOSIA M, RASIDIMANANA VT, RABARison H, Cheplogoi PK, RATSimbason M, MULHOLland D AND MAUClÈre P. 2003. Plants traditionally prescribed to treat tazo (malaria) in the eastern region of Madagascar. Malaria J 2: 25-35.

Rathore D, JANi D, NAGARKATti R AND Kumar S. 2006. Heme detoxification and antimalarial drugs Known mechanisms and future prospects. Drug Discovery Today: Therapeutic Strategies 3: 153-158.

Rosenthal PJ. 2001. Antimalarial chemotherapy: mechanisms of action, resistence and new directions in drug discovery. Mem Inst Oswaldo Cruz 96: 1185-186.

Rosenthal PJ. 2003. Antimalarial drug discovery: old and new approaches. J Exp Biol 206: 3735-3744.

SANChEZ BAM, VAROTTI FP, RODRIGUES FG AND CARvalho LH. 2007. Validation of a Plasmodium falciparum parasite transformed with green fluorescent protein for antimalarial drug screening. J Microbiological Methods 20: 1-5.

Saxena S, Pant N, Jain DC and Bhaluni RS. 2003. Antimalarial agents from plant sources. Current Sci 85: 1314-1329.

SchwikKard S AND VAN HEERden FR. 2002. Antimalarial activity of plant metabolites. Nat Prod Report 19: 675-692. 
Silva THA, Oliveira AB AND Almeida WB. 1997. Conformational analysis of the antimalarial agent quinine. Structural Chem 8: 95-107.

Silva THA, Oliveira SAntos HF AND Almeida WB. 2001. Conformational analysis of epiquinine and epiquinidine. Structural Chem 12: 431-437.

Silva THA, Oliveira MT, SAntos HF, Oliveira AB AND ALMEIDA WB. 2005. Molecular modeling study of complexes between ferriprotoporphyrin IX and antimalarial 4-quinolinecarbinolamines: a proposal of pharmacophore. Química Nova 28: 244-249.

STEELE JCP, VEITCH NC, KIT GC, SIMMONDS MSJ AND WARHURST DC. 2002. Indole and $\beta$-caboline alkaloids from Geissospermum sericeum. J Nat Prod 65: 85-88.

Sullivan DJ. 2002. Theories on malarial pigment formation and quinoline action. Int J Parasitol 32: 1645-1653.

TAgboto S And Townson S. 2001. Antiparasitic properties of medicinal plants and other naturally occurring products. Advances in Parasitol 50: 199-295.

TAUIL PL. 2003. Evaluation of a new strategy in the malaria control in the Brazilian Amazon. Rev Inst Med Trop São Paulo 45: 306.

TRAGER W AND JENSEN JB. 1976. Human malaria parasites in continuous culture. Science 193: 673-675.

WARHURST DC. 1981. The quinine-haemin interaction and its relationship to antimalarial activity. Biochem Pharmacol 30: 3323-3327.

WATERMAN PG. 1999. The chemical systematics of alkaloids: A review emphasising the contribution of Robert Hegnauer. Biochem System Ecol 27: 395-406.
Weniger B, Robledo S, Arango GJ, Deharo E, Aragon R, Muñoz V, Callapa J, Lobstein A AND ANTON R. 2001. Antiprotozoal activities of Colombia plants. J Ethnopharmacol 78:193-200.

WHO. 2005. World Malaria Report. Geneva, World Health Organization, http://rbm.who.int/wmr.2005.

WHO. 2008. World Malaria Report. Geneva, World Health Organization. http://rbm.who.int/wmr.2008.

Willcox ML AND BodeKer G. 2004. Traditional herbal medicines for malaria. Brit Med J 329: 1156-1159.

Winter RW, Kelly JX, Smilkstein MJ, Dodean R, BABby GC, RATHBUN RK, LEVIN Ji, Hinticks D AND RISCOE MK. 2006. Evaluation and lead optimization of antimalarial acridones. Exp Parasitol 114: 47-56.

Wright CW. 2005a. Plant derived antimalarial agents: New leads and challenges. Phytochem Rev 4: 55-61.

Wright CW. 2005b. Traditional antimalarial and the development of novel antimalarial drugs. J Ethnopharmacol 100: $67-71$.

Wright CW, Allen D, Phillipson JD, Kirby GC, WARhurst DC, MAssiot G AND Men-Olivier LL. 1993. Alstonia species: are they effective in malaria treatment? J Ethnopharmacol 40: 41-45.

Wright CW, Addae-Kyereme J, Breen AG, Brown JE, Cox MF, Croft SL, GoKçeK Y, Kendrick H, Phillips RM AND POllet PL. 2001. Synthesis and evaluation of cryptolepine analogues for their potential as new antimalarial agents. J Med Chem 44: 3187-3194. 